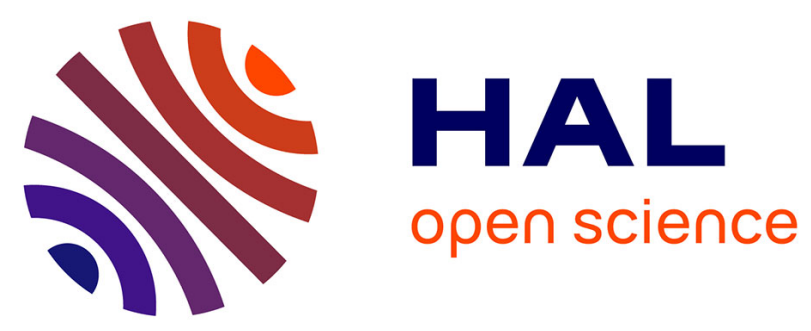

\title{
Potential of satellite rainfall products to predict Niger River flood events in Niamey
}

C. Casse, Marielle Gosset, C. Peugeot, V. Pedinotti, Aaron Anthony Boone, B. A. Tanimoun, B. Decharme

\section{- To cite this version:}

C. Casse, Marielle Gosset, C. Peugeot, V. Pedinotti, Aaron Anthony Boone, et al.. Potential of satellite rainfall products to predict Niger River flood events in Niamey. Atmospheric Research, 2015, 163, pp.162-176. 10.1016/j.atmosres.2015.01.010 . hal-02267949

\section{HAL Id: hal-02267949 \\ https://hal.science/hal-02267949}

Submitted on 20 Aug 2019

HAL is a multi-disciplinary open access archive for the deposit and dissemination of scientific research documents, whether they are published or not. The documents may come from teaching and research institutions in France or abroad, or from public or private research centers.
L'archive ouverte pluridisciplinaire HAL, est destinée au dépôt et à la diffusion de documents scientifiques de niveau recherche, publiés ou non, émanant des établissements d'enseignement et de recherche français ou étrangers, des laboratoires publics ou privés. 


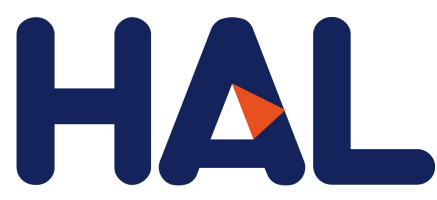

archives-ouvertes

\section{Potential of satellite rainfall products to predict Niger River flood events in Niamey}

C. Casse, M. Gosset, C. Peugeot, V. Pedinotti, Aaron Boone, B. Tanimoun, B. Decharme, A. Tanimoun

\section{- To cite this version:}

C. Casse, M. Gosset, C. Peugeot, V. Pedinotti, Aaron Boone, et al.. Potential of satellite rainfall products to predict Niger River flood events in Niamey. Atmospheric Research, Elsevier, 2015, 163, pp.162-176. 10.1016/j.atmosres.2015.01.010 . hal-02267949

\section{HAL Id: hal-02267949 \\ https://hal.archives-ouvertes.fr/hal-02267949}

Submitted on 20 Aug 2019

HAL is a multi-disciplinary open access archive for the deposit and dissemination of scientific research documents, whether they are published or not. The documents may come from teaching and research institutions in France or abroad, or from public or private research centers.
L'archive ouverte pluridisciplinaire HAL, est destinée au dépôt et à la diffusion de documents scientifiques de niveau recherche, publiés ou non, émanant des établissements d'enseignement et de recherche français ou étrangers, des laboratoires publics ou privés. 


\title{
Potential of satellite rainfall products to predict Niger River flood events in Niamey
}

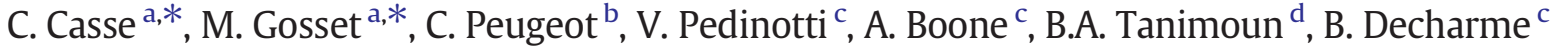 \\ a Géoscience Environnement Toulouse (GET) (UMR 5563 CNRS, IRD, Université Toulouse III), Observatoire Midi-Pyrénées, Toulouse, France \\ b HydroSciences Montpellier (HSM) (UMR 5569, CNRS, IRD, Université Montpellier I, II), France \\ c Centre National de Recherche Météorologique (CNRM) (UMR 3589, CNRS, Météo France), Toulouse, France \\ d Autorité du Bassin du Niger (ABN), Niamey, Niger
}

\section{A R T I C L E I N F O}

\section{Article history:}

Received 12 May 2014

Received in revised form 12 January 2015

Accepted 14 January 2015

Available online $\mathrm{xxxx}$

\section{Keywords:}

Floods

Satellite rainfall estimates

Sahel

Niger River

Hydrological modelling

Tropical hydrology

\begin{abstract}
A B S T R A C T
A dramatic increase in the frequency and intensity of flood events in the city of Niamey, Niger, has been observed in the last decade. The Niger River exhibits a double outflow peak in Niamey. The first peak, is due to the rainfall occurring within about $500 \mathrm{~km}$ of Niamey. It has reached high values in recent years and caused four drastic flood events since 2000. This paper analyses the potential of satellite rainfall products combined with hydrological modelling to monitor these floods. The study focuses on the $125,000 \mathrm{~km}^{2}$ area in the vicinity of Niamey, where local runoff supplies the first flood. Six rainfall products are tested : a gauge only product - the Climate Prediction Centre (CPC); two gauge adjusted satellite products - the Tropical Rainfall Measurement Mission (TRMM) Multi-Platform Analysis (TMPA 3B42v7) and the CPC regional product African Rainfall Estimate (RFE version 2); and three satellite only products, 3B42RT, the CPC Morphing method (CMORPH) and the Precipitation Estimation from Remotely Sensed Information using Artificial Neural Network (PERSIANN). The products are first inter-compared over the region of interest. Differences in terms of rainfall amount, number of rainy days, spacial extension of the rainfall events and frequency distribution of the rain rates are highlighted. The satellite only products provide more rain than the gauge adjusted ones. The hydrological model ISBA-TRIP is forced with the six products and the simulated discharge is analysed and compared with the discharge observed in Niamey over the period 2000 to 2013 . The simulations based on the satellite only rainfall produce an excess in the discharge. For flood prediction, the problem can be overcome by a prior adjustment of the products - as done here with probability matching - or by analysing the simulated discharge in terms of percentile or anomaly. All tested products exhibit some skills in detecting the relatively heavy rainfall that preceded the flood and in predicting that the 95th percentile of the discharge (i.e., the flood alert level in Niamey) will be exceeded. These skills are however variable among products and the best overall results are obtained with the TMPA 3B42 products.
\end{abstract}

\section{Introduction}

Three recent floods on the Niger river have resulted in substantial damage in Niamey in 2010, (Sighomnou et al., 2010;

\footnotetext{
* Corresponding authors at: GET (UMR 5563 CNRS, IRD, UTIII), Observatoire Midi-Pyrénées, 14 avenue Edouard Belin, 31400 Toulouse, France.

E-mail addresses: claire.casse@get.obs-mip.fr (C. Casse), marielle.gosset@ird.fr (M. Gosset).
}

Descroix et al., 2012), 2012 (Sighomnou, 2012; Sighomnou et al., 2013; OXFAM and ACTED report, 2012) and 2013 (Niger Basin Authority, ABN, website, http://www.abn.ne/), causing flooding, property damage and significant loss of life among people living near the river. These events have brought the attention of the media in a region traditionally known for its droughts rather than its floods. The analysis of these recent flood events has shown that they are related to a drastic change in the hydrological regime of the Niger basin in the region around 
Niamey (Descroix et al., 2012). Despite the severe droughts and a general decrease of the Niger river discharge (Albergel, 1987; Briquet et al., 1996; Mahé et al., 2003), the Niger River's right bank tributaries and other Sahelian rivers (Mahé et al., 2003, 2005; Descroix et al., 2009) have shown an increase in discharge, since the 1970s. This is attributed to changes in the runoff response of the watersheds (Albergel, 1987; Amani and Nguetora, 2002; Mahé and Paturel, 2009; Amogu et al., 2010) resulting from the droughts impact on vegetation cover, land cover clearing and subsequent increased soil crusting (Leblanc et al., 2008; Gardelle et al., 2010). The increase of runoff in the Niger River's right bank tributaries catchment resulted in a modification of the Niger river's regime near Niamey since the 80s, from a single to a double flood hydrograph (Amani and Nguetora, 2002; Descroix et al., 2012; Sighomnou et al., 2013). The first flood occurs during the rainy season and is a direct consequence of rainfall over the Niger River's right bank tributaries in the vicinity of Niamey. This first flood is now frequently more pronounced than the second one, and has caused four major flood events since 2000.

In addition to land-use changes, recent observations have raised the issue of a possible increase in extreme rainfall in the Sahel (Panthou et al., 2012, 2014). This could be the premises of an intensification of the hydrological cycle due to global warming (Giorgi et al., 2011) as already observed in other regions (Alpert, 2002). The risk of flood events is expected to increase if the land use changes continue, whether or not the increased frequency of rainfall extremes is confirmed. To reduce these risks, the flood genesis needs to be better understood and adequate monitoring systems need to be developed.

Currently, the monitoring of the flood risk in Niamey is based essentially on the surveillance of the river height upstream of Niamey. This is suitable for monitoring the second flood, which occurs between January and March, a few months after the end of the rainy season in Niamey. The first flood, which occurs in the heart of the rainy season is a more rapid phenomenon and is a consequence of runoff in the vicinity of Niamey. To predict this first flood the contributing rainfall must be precisely quantified. Given the relatively poor state of the operational gauge network in the area, satellite based rainfall is a very attractive alternative (Hossain et al., 2004). Further benefits of satellite rainfall estimates lie in their spatial and temporal resolutions $\left(0.5^{\circ}, 3\right.$ hourly or better $)$ and in the near real-time availability of some products. However, as already discussed at length for radar based estimates (Berne and Krajewski, 2012 for a review), the potential benefit of high resolution may be outbalanced by the uncertainties and/or biases in the remotely sensed rainfall. These uncertainties and the way they might propagate in hydrological models (Hossain et al., 2004; Hong et al., 2006; Moradkhani et al., 2006; Nikolopoulos et al., 2010) need to be accounted for before any satellite rainfall product is considered for operational prediction.

Several recent works have evaluated satellite rainfall products over Africa based on gauges (Ali et al., 2005; Hughes, 2006; Roca et al., 2010; Jobard et al., 2011; Pierre et al., 2011; Habib et al., 2012; Thiemig et al., 2012; Gosset et al., 2013) and discussed their potential utility for the hydrological prediction of several African rivers (Nile tributaries - Artan et al., 2007; Gilgel Abay - Bitew and Gebremichael, 2011; Senegal river Stisen and Sandholt, 2010; Volta and Baro-Akobo - Thiemig et al., 2013). Findings are consistent among these papers on the performance of some of the most commonly used product, in the Sahelian region. The products that do not ingest any gauge information - Precipitation estimation from Remotely Sensed Information using Artificial Neural Network (PERSIANN), Climate Prediction Centre (CPC) Morphing method (CMORPH) and Tropical Rain Measurement Mission (TRMM) Multi-platform Algorithm (TMPA, 3B42RT) - exhibit positive biases which may cause overestimation of the runoff and discharge when used in hydrological modelling (Thiemig et al., 2012; Gosset et al., 2013). Thiemig et al. (2013) have compared different methods for correcting the biases in the rainfall forcing, either by correcting the products themselves or by adjusting the model to the products (through recalibration for each type of rain forcing). The gauge adjusted products - TMPA 3B42v7 and the CPC regional product African Rainfall Estimate RFE2 - have generally low biases (at least at the monthly scale) but are not free of errors and may distort the spatial or frequency distribution of the rain rates (Gosset et al., 2013), with consequences for hydrology.

In this paper, we analyse the potential of six state of the art rainfall products combined with numerical modelling to analyse and assess the predictability of the Niger river first flood: a gauge only product $(\mathrm{CPC})$, two gauge adjusted satellite products (3B42v7 and RFE2) and three satellite only products (3B42RT, CMORPH and PERSIANN). The study focuses on the ability of the model forced by satellite rainfall to reproduce the relatively high discharge levels encountered in recent years, and simulate the occurrence and length of floods.

Section 2 presents the hydrological context and the behaviour of the first flood observed in Niamey over the last 14 years. Section 3 describes the six rainfall products and compares some of their properties over the studied region. A bias-adjustment of the three products that do not ingest any gauge information is proposed. Section 4 presents the numerical modelling setup, based on the SURFEX platform (SURFace EXternalisée, in French) - ISBA (Interaction between Soil, Biosphere and Atmosphere) land surface model coupled with the TRIP (Trip Runoff Integrating Pathways) routing scheme. Section 5 discusses the simulation results. The discharges simulated with each rainfall product are compared with the observations over the period 2010-2013. The ability of the satellite forced simulations to reproduce the occurrence of the major floods of the period is quantified. The conclusions and perspective of this work are given in Section 6 .

\section{Hydrological context}

The Niger River (Fig. 1) flows through a large part of West Africa. Its source is located in the humid mountainous Fouta Djallon area of Guinea. It initially flows northwards towards the Malian Sahel before turning south-eastwards towards Niamey and finishing its $4200 \mathrm{~km}$ long journey in Nigeria (Andersen et al., 2005; Ferry et al., 2012). An original feature of the Niger is its 'inner delta' (the light orange area in Fig. 1), which is characterized by a large lateral expansion of the river and large evaporation losses (Andersen et al., 2005). Around 60\% of the inflow is lost in the Delta (Mahé et al., 2009).

Due to weakly connected drainage networks and aridity (so-called endorheism), most of the northern part of the basin does not contribute to the river flow. The river flow in Niamey originates from areas upstream the delta and from active tributaries downstream of the Niger-Mali border. As a 


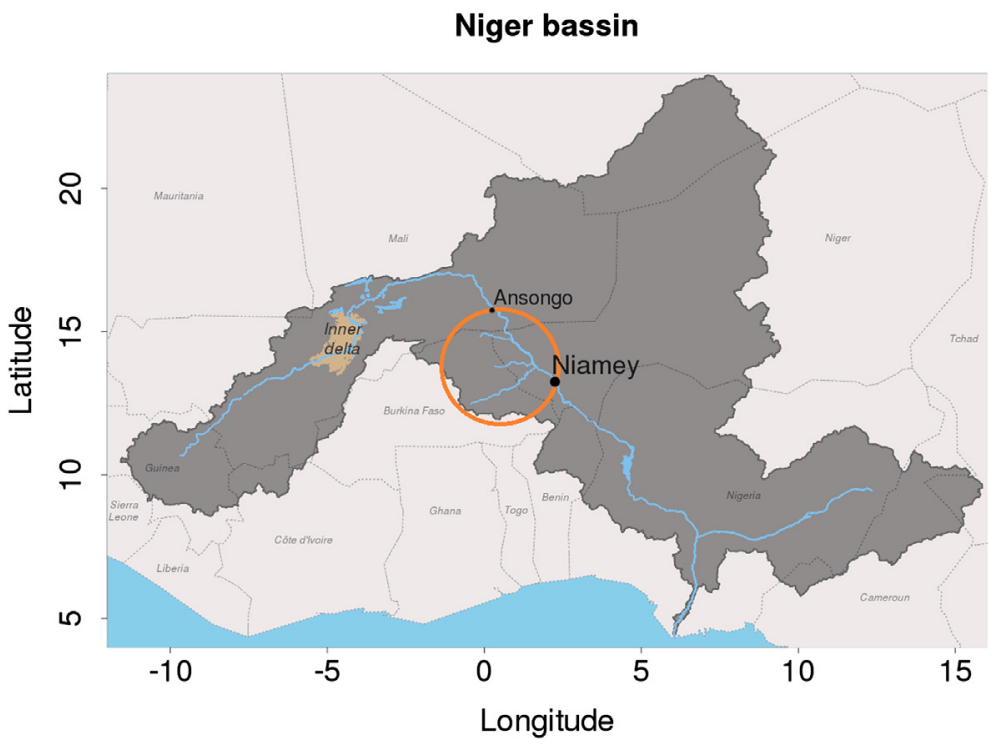

Fig. 1. The Niger River Basin. The circle delineates the right bank basins that contribute to the first or 'red' flood (see text). Only the three tributaries relevant for the study are drawn.

consequence, the Niger River in Niamey exhibits two peaks (Fig. 2). The first peak occurs between August and September. It is due to the heavy monsoon rainfall occurring in August over the basins of three right bank tributaries (circled in Fig. 1): the Gorouol River (basin area 44,900 $\mathrm{km}^{2}$ ), the Dargol $\left(6940 \mathrm{~km}^{2}\right.$ ) and the Sirba $\left(38,750 \mathrm{~km}^{2}\right)$. These ephemeral rivers (termed "koris") and a series of smaller koris on both banks $\left(27,020 \mathrm{~km}^{2}\right)$ define a contributing area of $117,610 \mathrm{~km}^{2}$ (Descroix et al., 2012). The first flood is also named 'red flood' because of the colour of its sedimentary load. The second peak results from runoff during the rainy season (June-September) in the upper basin. The resulting flood wave is smoothed and delayed by routing through the Niger Inner Delta, and occurs in Niamey around

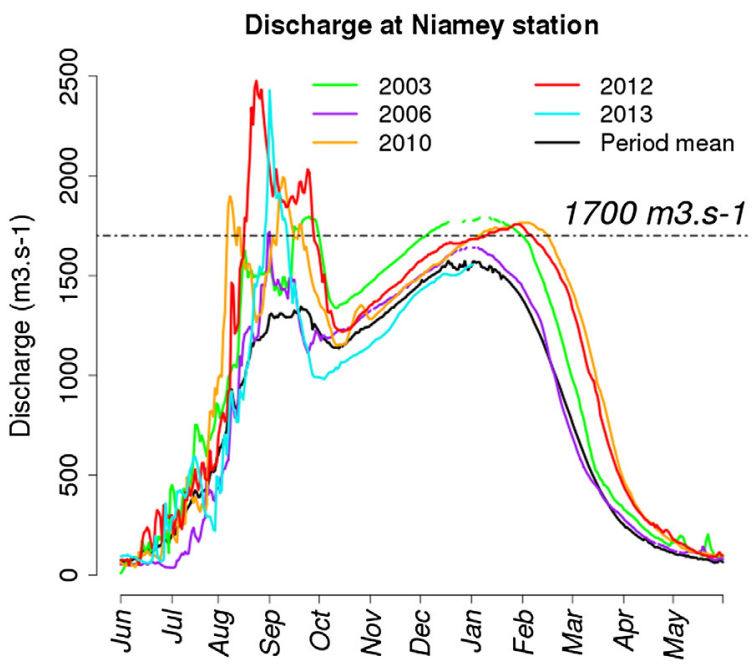

Fig. 2. Niger river discharge in Niamey for the indicated years; the black line is the average discharge for the period 2000-2013 studied in this work. The horizontal dash line is the flood threshold.
January (Fig. 2). Because of it origin the second flood is also named the Guinean flood.

In the past, the two floods used to be merged into a single peak (Amani and Nguetora, 2002; Descroix et al., 2012), but since the 1970s, the first gradually became distinct from the second. Descroix et al. (2012) described this change with the poetic image: 'the dromedary became a camel'. The first flood has intensified in the last decade because of the increase in runoff in the Sahelian zone (Albergel, 1987; Amani and Nguetora, 2002; Mahé et al., 2003, 2005; Mahé and Paturel, 2009; Amogu et al., 2010; Descroix et al., 2009, 2012).

As seen in Fig. 2, the two discharge peaks are lagged in time, and the delay between the two peaks makes it possible to study independently the local rapid Sahelian contributions and the slower signal due to the Guinean flood.

The threshold of $1700 \mathrm{~m}^{3} \mathrm{~s}^{-1}$ (equivalent to a river height of $530 \mathrm{~cm}$ ) is indicated in Fig. 2. According to the Niger Basin Authority (NBA or ABN in French), this is the critical height that triggers flooding. Since 2000 the discharge in Niamey exceeded this threshold during five years: 2006, 2003, 2010, 2012 and 2013 (Table 1). The most recent floods, 2010, 2012 and 2013 were exceptional in their intensity (maximum discharge rates between 1993 and $2429 \mathrm{~m}^{3} \mathrm{~s}^{-1}$ ) and/or their duration. These are three consecutive records for the first flood since the beginning of discharge observation in Niamey in 1920s. Note that the 2013 flood pattern differs from the other floods: the first flood is brief and intense, and the discharge minimum between the first and the second flood is the lowest of the studied period.

In order to distinguish which part of the first flood can be attributed to the three right bank and other local tributaries,

Table 1

Observed period of flood (number of consecutive day) between 2000 and 2013.

\begin{tabular}{llllll}
\hline & 2003 & 2006 & 2010 & 2012 & 2013 \\
\hline Number of day above $1700 \mathrm{~m}^{3} \mathrm{~s}^{-1}$ & 15 & 2 & 7,12 & 42 & 14
\end{tabular}


and which part comes from the main course of the river (due to rainfall contribution in Mali) the discharge difference between Niamey and Ansongo is analysed. Fig. 3 presents the accumulated discharge in Ansongo and in Niamey, for the 10 day period preceding the 1 st flood peak in Niamey. The difference between Ansongo and Niamey comes from the contribution of the right bank tributaries. A time lag is applied to the Ansongo discharge (1 day) to account for transfer time between Ansongo and Niamey. The lag value has been computed based on optimising the lagged correlation between the time series of Ansongo and Niamey.

Among the 5 years when the flooding threshold is exceeded (i.e., 2003, 2006, 2010, 2012 and 2013) 2003 and 2010 stand out as the years when the Ansongo contribution is larger than the local tributaries contribution. In 2006 both contributions were equivalent. In 2012 the contribution from the local tributaries is high, revealing high rainfall accumulation nearby Niamey. The discharge information at Ansongo is not available for 2013 (problem in the data record); Fig. 3 shows only the Niamey discharge for this year.

In the rest of the paper, we focus on the hydrological impact of the rainfall contributing to the local tributaries of the Niger river (circled in Fig. 1); this zone will be referred to as "the region of Niamey" or "region of interest" hereafter.

\section{Rainfall products}

\subsection{Tested rainfall products}

Among the variety of available rainfall products (see an overview on the IPWG website www.isac.cnr.it/iipwg/), five satellite estimates were considered (Table 2). This choice is made owing to the availability of the products over the 2000-2013 period, when 4 major floods occurred (2003, 2010, 2012, 2013). This study also focuses on products that could be easily utilised in an operational setting because they are available online. Three of the most used near real time global estimates are tested :

- CMORPH (Joyce et al., 2004)

- PERSIANN (Sorooshian et al., 2000)

- 3B42RT (Huffman et al., 2007).

These three rainfall products are not gauge adjusted and are therefore available with a relatively short delay ranging from a few hours (3B42RT) to two days (CMORPH). For simplification, these products are referred to as 'RT' (for near Real Time) in the rest of the paper. These RT products have been evaluated recently through a comparison with the AMMA-CATCH observatory (Lebel et al., 2009) dense gauges network in Niamey. The comparison was done at the daily and 1 degree scale in Gosset et al. (2013) and at an even finer resolution in Guilloteau et al. (2014). Both studies concluded that these RT products exhibit medium to high positive biases compared to the ground reference. They also showed that the products that combine infrared and microwave information exhibit very good correlation with ground observations, in terms of their daily time series (Gosset et al., 2013; Roca et al., 2010) and sub-degree scale spatial structure (Guilloteau et al., 2014). CMORPH exhibits the best scores in terms of correlation and 3B42RT performs best in terms of bias.

In addition to the three satellite-only products, estimators that also ingest rain gauge data are tested :

- 3B42v7 (Huffman et al., 2007). According to Gosset et al. (2013) and Guilloteau et al. (2014), the performance of this product compared to gauges (and to other products) over Niamey is high when numerous statistical criteria are

\section{0 day cumulated discharge}

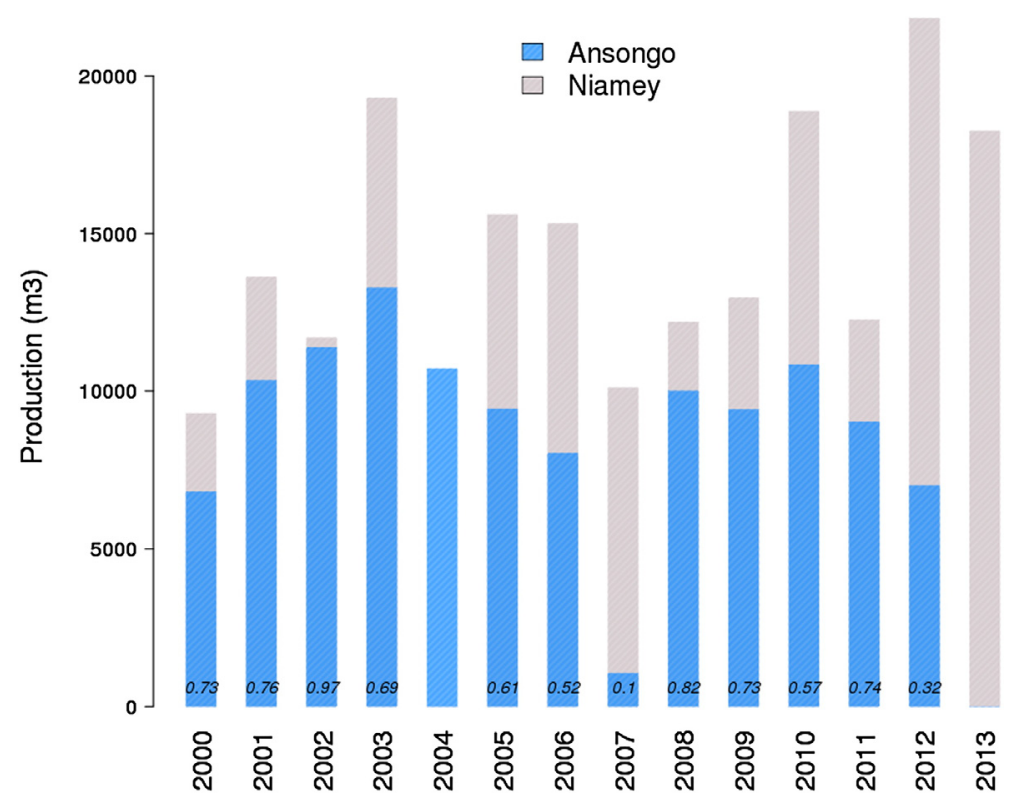

Fig. 3. 10 day cumulated discharge (before the observed discharge peak in Niamey; not fully available for 2004) for Ansongo (blue; not available in 2013) and Niamey (grey). The ratio Ansongo over Niamey is indicated on each bar. (For interpretation of the references to colour in this figure legend, the reader is referred to the web version of this article.) 
Table 2

Main characteristics of the six tested rainfall products.

\begin{tabular}{|c|c|c|c|c|c|c|}
\hline & Ingested data & $\begin{array}{l}\text { Region } \\
\text { covered }\end{array}$ & $\begin{array}{l}\text { Temporal } \\
\text { resolution }\end{array}$ & $\begin{array}{l}\text { Spatial } \\
\text { resolution }\end{array}$ & $\begin{array}{l}\text { Period } \\
\text { tested }\end{array}$ & Data access website \\
\hline $\mathrm{CPC}$ & Rain gauges & Global & Daily & $0.5^{\circ}$ & 2000 to 2013 & http://www.cpc.noaa.gov/products/fews/data.html \\
\hline RFE2 & Satellite + Gauges & Regional Africa & Daily & $0.1^{\circ}$ & 2001 to 2013 & http://www.cpc.noaa.gov/products/fews/data.html \\
\hline TRMM 3B42v7 & Satellite + Gauges & Global & $3 \mathrm{~h}$ & $0.25^{\circ}$ & 2000 to 2013 & http://trmm.gsfc.nasa.gov/ \\
\hline TRMM 3B42RT & Satellite & Global & $3 \mathrm{~h}$ & $0.25^{\circ}$ & 2000 to 2013 & http://trmm.gsfc.nasa.gov/ \\
\hline CMORPH & Satellite & Global & $3 \mathrm{~h}$ & $0.25^{\circ}$ & 2003 to 2013 & http://www.cpc.noaa.gov/products/fews/data.html \\
\hline PERSIANN & Satellite & Global & $3 \mathrm{~h}$ & $0.25^{\circ}$ & 2000 to 2013 & http://chrs.web.uci.edu/persiann \\
\hline
\end{tabular}

considered (overall bias; correlation of the time series and spatial patterns; frequency distribution of the rain rates). This is the only product in our test set available with a long delay (a month).

- RFE2 (Herman et al., 1997; www.cpc.ncep.noaa.gov/products/ fews/data.html\#rfe2). The evaluation of RFE2 over the Sahel showed that the performance is good at the 10 day scale (Jobard et al., 2011) and the bias is very low (Gosset et al., 2013). However, when evaluated at the daily time step, this product tends to overestimate the number of rainy days (Gosset et al., 2013; Hermance and Sulieman, 2013) and distorts the frequency distribution of rain rates (Gosset et al., 2013).

Finally, a gauge-only product available with a very short delay (less than 2 days) was also used. The CPC product (Xie and Arkin, 1997) uses operational daily gauge information transmitted through the Global Telecommunication System (GTS). In addition to the daily mean rainfall estimate over a $0.5^{\circ}$ grid, CPC also provides the number of gauges utilised per pixel. In the region of interest, the density of gauges is low. For each pixel of the CPC product the maximum number of rain gauges is 1. The daily mean number of gauges over the $125000 \mathrm{~km}^{2}$ study area, between 2000 and 2013, is $5.2( \pm 0.66)$. Therefore we can expect uncertainties in the CPC product due to a substantial spatial representativeness error and smoothing.

\subsection{Observed differences between the products}

As mentioned above, the satellite rainfall products have already been evaluated in Sahelian Africa by various authors who concentrated on different spatio-temporal scales: monthly and 10 days in Jobard et al. (2011) and Pierre et al. (2011); daily and 1 degrees in Gosset et al. (2013) and Roca et al. (2010), and even finer resolution in Guilloteau et al. (2014). In this section, we concentrate on the observed differences between the products over the catchment between Ansongo and Niamey $\left(125,000 \mathrm{~km}^{2}\right)$. Analyzing the physical and algorithmic reasons behind these differences is not in the scope of this paper; the objective is to quantify the differences and assess how they may (or not) impact flood prediction.

\subsubsection{Rainfall accumulation, Inter-annual variability, intensity distributions}

Table 3 compares the mean rainfall (JJAS) over the 20032013 period for the 6 products. As expected, the seasonal (JJAS) rainfall accumulation of the two post-adjusted satellite products (3B42v7 and RFE2) are very close to the gauge product (CPC) which produces $406 \mathrm{~mm}$ of rain on average. As found in previous studies, the RT products provide more rain than the products that ingest the gauge information. 3B42RT and CMORPH rainfall accumulation are of the same order of magnitude (respectively $620 \mathrm{~mm}$ and $660 \mathrm{~mm}$ ) and are about 50\% higher than the amount from gauges or gauge-adjusted products. PERSIANN exhibits the highest amount $(928 \mathrm{~mm}$ ) producing about twice as much rain as the gauge-adjusted products. These numbers are consistent with the positive bias reported by several authors that compared the RT products with a ground reference (Roca et al., 2010; Jobard et al., 2011; Pierre et al., 2011; Thiemig et al., 2012; Gosset et al., 2013; Guilloteau et al., accepted for publication).

Fig. 4 highlights the differences among products in terms of seasonal (JJAS) accumulation (a), number of rainy days (b), mean conditional daily rainfall (c) and spatial extension of the daily rain patterns (d) over the period 2000-2013. The mean conditional daily rainfall is calculated for pixels with at least $0.5 \mathrm{~mm} /$ day. The spatial extension is the percentage of pixels with at least $0.5 \mathrm{~mm}$ on days when the mean areal rainfall over the domain is above $0.5 \mathrm{~mm}$.

Unlike the season total (Fig. 4a), the temporal and spatial distributions of rainfall vary substantially among the 3 products that ingest gauge information. CPC and RFE2 tend to spread the rainfall over more rainy days (Fig. $4 \mathrm{~b}$ ), and for each day, over a larger part of the basin (Fig. 4d) than 3B42v7. Rainfall events cover about $65-70 \%$ of the region of interest for CPC and RFE, and less than $50 \%$ for 3B42v7. On the opposite, the mean conditional rainfall (Fig. 4c) is higher for 3B42v7 (just above $10 \mathrm{~mm}$ /day on average) than for RFE2 and CPC (both below $10 \mathrm{~mm} /$ day). These differences are expected to impact the hydrological response. The low number of gauges that is actually available over the region in CPC, explains why this product tends to smooth the rainfall information. The differences between 3B42v7 and RFE, comes from the nature of the algorithms and the fact that 3B42, unlike RFE, uses microwave information in addition to the infrared data as detailed in their reference papers.

The 3 RT products provide more rainfall than the gaugeadjusted products, steadily over the years. Further analysis has

\section{Table 3}

Inter-annual mean of the JJAS rainfall \pm standard deviation for the period 2003-2013. The three last lines refer to the bias-adjusted RT product described in Section 3.2.2.

\begin{tabular}{ll}
\hline & Areal mean seasonal rainfall $[\mathrm{mm}]$ \\
\hline CPC & $406 \pm 71$ \\
RFE2 & $448 \pm 79$ \\
TRMM3B42v7 & $417 \pm 77$ \\
TRMM3B42RT & $620 \pm 89$ \\
CMORPH & $660 \pm 107$ \\
PERSIANN & $928 \pm 171$ \\
TRMM3B42RT bias adjusted & $458 \pm 66$ \\
CMORPH bias adjusted & $413 \pm 71.5$ \\
PERSIANN bias adjusted & $439 \pm 109$ \\
\hline
\end{tabular}




\section{a) Annual rainfall}

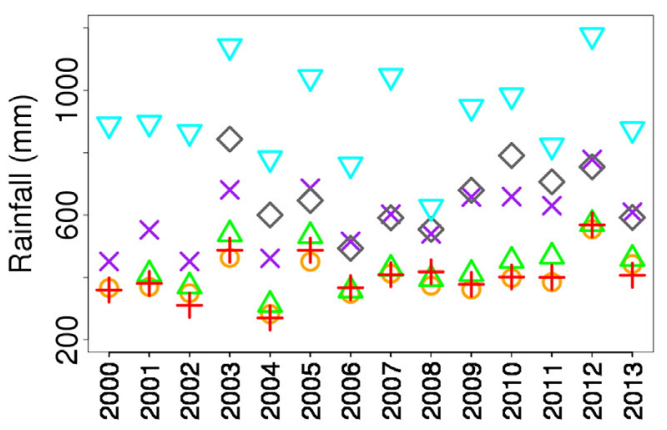

b) Mean conditional daily rainfall

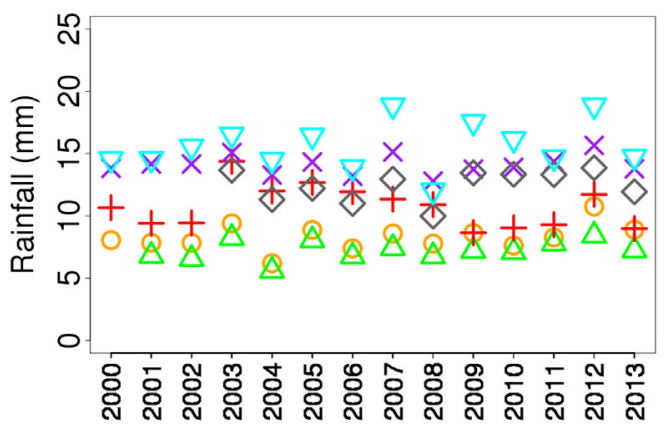

c) Rainy days

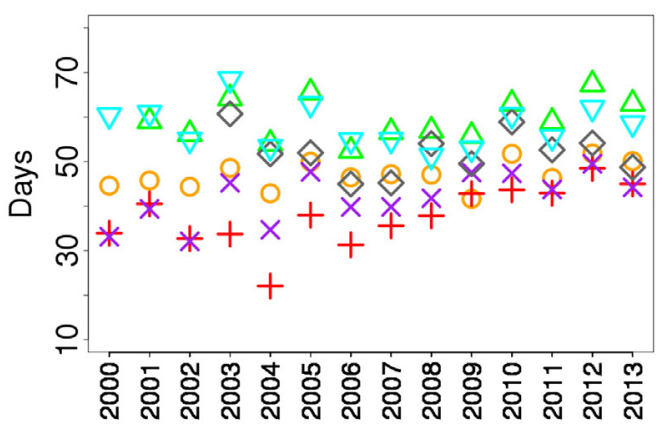

d) Rain event spatial extension

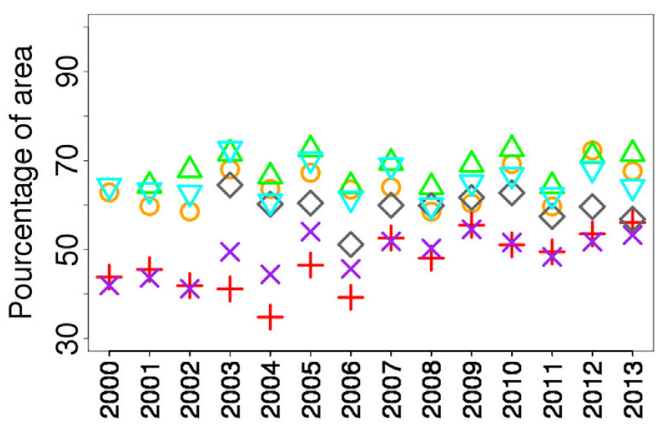

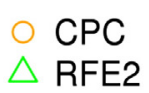

+ TRMM-3B42v7
$\times$ TRMM-3B42RT

\section{CMORPH PERSIANN}

Fig. 4. Inter-annual 2000-2013 rainfall series observed by the 6 tested products. a) mean areal seasonal rainfall; b) mean number of rainy days; c) mean conditional daily rainfall; d) mean \% of rain extension over the studied area (see text).

shown that the bias is the steadiest for 3B2RT, followed by PERSIANN, while CMORPH's bias is the most variable from year to year. All 3 RT products exhibit a relatively high mean conditional daily rainfall (Fig. 4c); 3B42RT and CMORPH are both about $13 \mathrm{~mm}$ /day on average, and PERSIANN, $14 \mathrm{~mm} /$ day. In terms of spatial extension and number of rainy days, there is no common trend among the 3RT products. PERSIANN generates more rainy days and more extended events than the 2 other RT; 3B42RT has the lowest number of rainy days and smaller spatial extension among the RT products.

It is noteworthy in Fig. 4 that the difference in the number of rainy days and spatial extension is higher among the 3 gaugeadjusted products, than for the 3 RT products; the largest difference being between RFE and 3B42v7.

An important consideration for hydrological applications is the distribution of the rainfall by intensity classes. Vischel and Lebel (2007) and Gosset et al. (2013), both focusing in West Africa, mentioned a strong sensitivity of the simulated runoff to the proportion of heavy rainfall. In the Sahel runoff production is indeed mainly conditioned by the contrast between rainfall intensities and soil hydraulic conductivity, as Hortonian processes are dominant (Peugeot et al., 1997).

Fig. 5 presents the frequency distribution of the daily rainfall (a) and the contribution of rain rate classes to the season total (b) computed for the region of interest, for JJAS and the period 2003-2013. Fig. 5b shows that the differences in the total rainfall among the products in mostly explained by the rainfall classes above $20 \mathrm{~mm} /$ day. As mentioned in previous studies, the three RT estimators produce a high proportion of intense (above $40 \mathrm{~mm} /$ day) rainfall. In contrast, the gauge-only product CPC produces much rain below $1 \mathrm{~mm}$ /day. This is most probably due to smoothing effects and the low density of the GTS gauge network in the region. A similar tendency to produce a relatively high proportion of low rain rates is found for RFE2. The 3 products that use the micro-wave information (3B42; PERSIANN and CMORPH) show a good agreement, with a relatively low amount of rain due to the classes 0.1 to $10 \mathrm{~mm} /$ day.

These results are consistent with those reported by many authors (Roca et al., 2010; Jobard et al., 2011; Pierre et al., 2011; Thiemig et al., 2012; Gosset et al., 2013; Guilloteau et al., accepted for publication): the products differ not only by their annual rainfall totals but also by the way rainfall is distributed in time, in space, and by rain intensity classes. These differences impact the simulated hydrological response when these products are used as forcing (Stisen and Sandholt, 2010; Gosset et al., 2013; Thiemig et al., 2013). Gosset et al. (2013) evaluated the 3 RT products by comparison with the dense network of gauges from AMMA-CATCH Niger (Lebel et al., 2009) near Niamey. They concluded that these products were positively biased and 

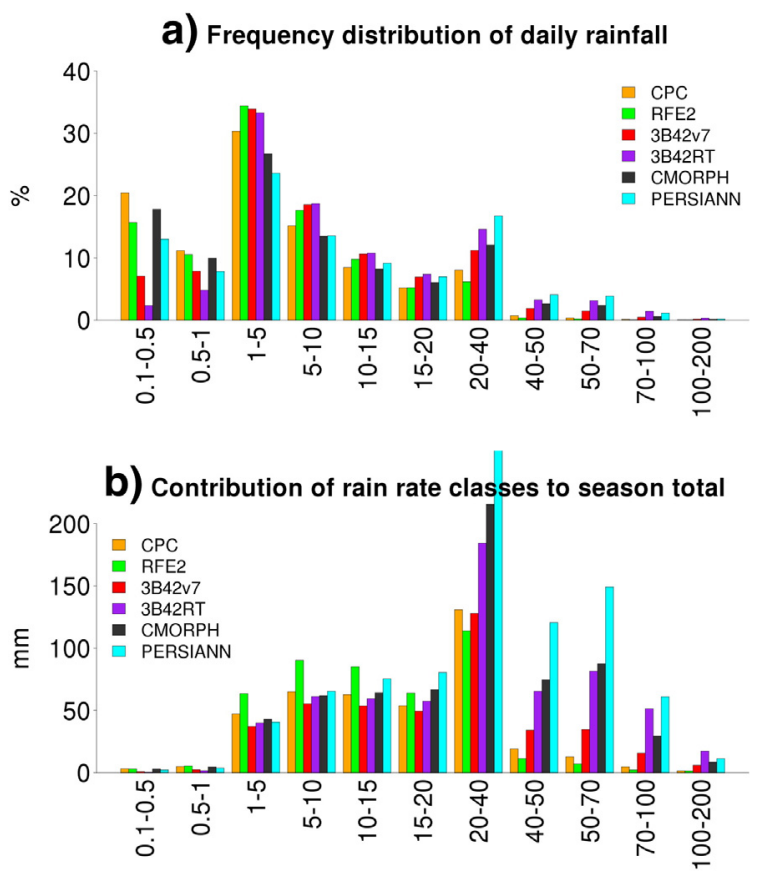

Fig. 5. a) Frequency distribution of daily rainfall for each product. b) Contribution of rain rate classes to the season total.

showed that they resulted in excess runoff when used as forcing to hydrological models. An adjustment of these 3 products is therefore proposed in the next section.

\subsubsection{Correction of the RT products}

The most common practice for bias-adjusting satellite rainfall products is to inject gauge information, as done for 3B42v7 and RFE2. If RT gauge information is not available (or if it is unreliable or the network density is too sparse for the information to be valuable), the correction can be done on a climatological basis. Probability matching between a series of satellite estimates and a reference rainfall time series is an accepted solution (Thiemig et al., 2013).

In the present case, the objective is to bias-adjust the rainfall products at the $0.5^{\circ} / 3 \mathrm{~h}$ resolution. At this resolution and given the low density of the gauge network in Africa, the ground reference based on gauges only is impacted by smoothing effects. Given the good performance previously reported for 3B42v7 (Gosset et al., 2013), and our own analysis based on the AMMA-CATCH Niger time series, it was decided to match the frequency distributions of the $3 \mathrm{RT}$ products to 3B42v7.

The principle of the probability matching method for correcting a series $Y=\left[y_{1}, y_{n}\right]$ based on the statistical properties of another variable $X=\left[x_{1}, x_{m}\right]$ is reviewed here. First, the cumulative distribution function (cdf) of both $\mathrm{Y}$ and $\mathrm{X}$ is calculated. Then, each value $y_{i}$, is replaced by the value in the series $\mathrm{X}$ which has the same $c d f$ value as $y_{i}$. For instance, if the cdf value of $y_{i}$ is $94 \%$ then $y_{i}$ is replaced by the 94 th percentile of the variable X.

An analytical formulation of the function that converts the $Y$ series is fit using a reference data set and then applied to any series of $Y$ that needs correction. The correction formulae were determined by comparing the series of each RT product with
3B42v7 over 10 years (2003-2013) over the studied area. A polynomial function with degree 2 or less was found adequate:

$Y_{\text {corr }}=\mathrm{a}+\mathrm{b} Y+\mathrm{c} Y^{2}$

where $Y_{\text {corr }}$ is the bias-adjusted product (set to 0 if it is negative) and $Y$ is the RT value. The formulae fitted for the $3 \mathrm{RT}$ products are given in Table 4 for information; please note that this correction was found to be adapted to the location and period where it was fitted and should not be used in other conditions. Table 4 is only informative.

The inter-annual characteristics of the bias-adjusted RT products and their frequency distributions are displayed in Figs. 6 and 7. After correction the rainfall accumulations and the proportion of high rain rates are in better agreement as seen in the figures and in Table 3. A simple, global correction such as the one implemented herein fails in the case of a strong interannual variability in the product performance. For instance, Fig. 4a shows that in 2008 PERSIANN accumulation is relatively lower than for the other years. Fig. 6 shows that for that year, the product correction brings PERSIANN below all the other products. The same is true for CMORPH in 2012. Further analysis would be needed and an adjustment of the products on a year to year basis might be better, however this is beyond the scope of the present analysis.

\section{Hydrological simulations set up}

\subsection{The SURFEX-ISBA-TRIP Model}

The hydrological simulation is based on the land surface model (LSM) ISBA (Interactions between Soil, Biosphere, and Atmosphere) coupled with the routing scheme TRIP (Total Runoff Integrating Pathways) within the SURFEX platform (www.cnrm.meteo.fr/surfex/, Masson et al., 2013) developed at MeteoFrance.

ISBA was initially developed by Noilhan and Planton (1989). Some developments have been done to improve the hydrological modelling, such as: the inclusion of a third soil layer (forcerestore soil method, Boone et al., 1999), the implementation of a sub-grid hydrology describing Dunne and Horton runoff (Decharme and Douville, 2005), and the implementation of an exponential profile of the saturated hydraulic conductivity with soil depth (Decharme and Douville, 2005; Decharme et al., 2006).

The TRIP routing scheme was developed at the Tokyo University by Oki and Sud (1998). Initially it converted the ISBA simulation runoff into river discharge thanks to a global river channel network and a single surface reservoir $(S)$. $S$ is linearly related to river mass, using a uniform and constant flow velocity $\left(0.5 \mathrm{~m} \mathrm{~s}^{-1}\right)$. The latest version of TRIP coupled with ISBA takes into account a variable flow velocity computed via Manning equation (Eq. (2)) (Decharme et al., 2010), a groundwater

Table 4

Coefficients of the polynomial fit used to correct the 3 RT products (Eq. (1)).

\begin{tabular}{llll}
\hline & $\mathrm{a}$ & $\mathrm{b}$ & $\mathrm{c}$ \\
\hline TRMM3B42RT & -0.01 & 0.74 & 0 \\
CMORPH & -0.048 & 0.567 & 0.004 \\
PERSIANN & -0.623 & 0.376 & 0.01 \\
\hline
\end{tabular}


a) Annual rainfall

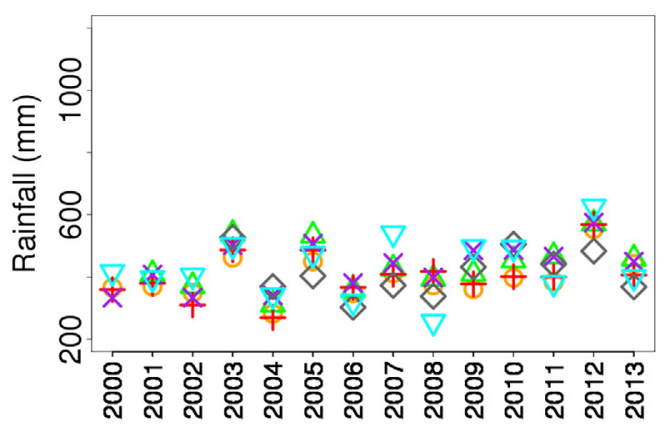

b) Mean conditional daily rainfall

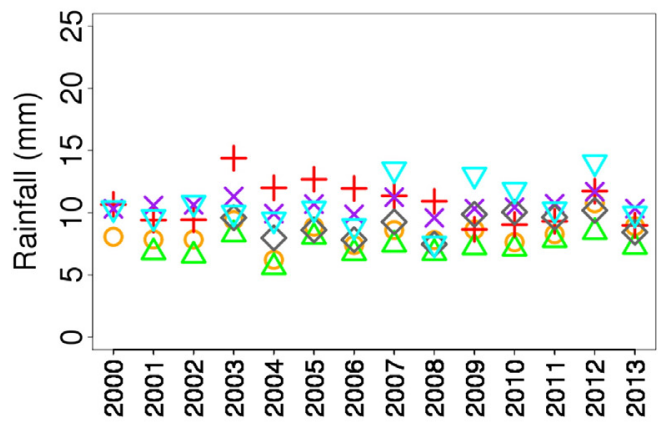

c) Rainy days

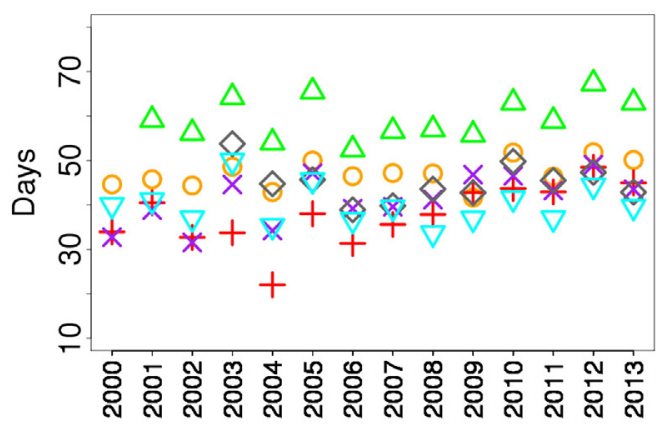

d) Rain event spatial extension

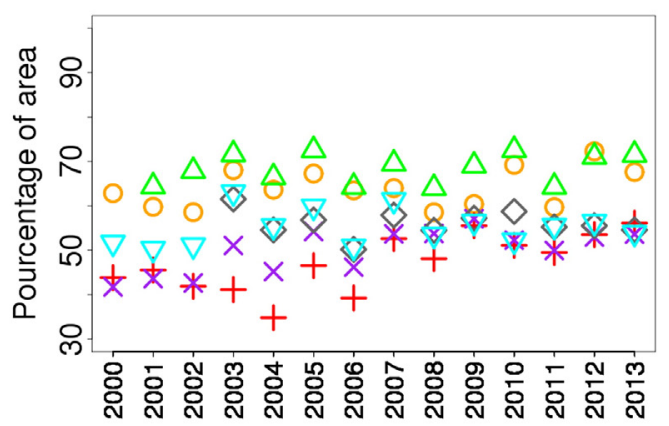

\section{CPC}

RFE2
+ TRMM-3B42v7

$\times$ TRMM-3B42RT adjusted bias

\section{CMORPH adjusted bias} PERSIANN adjusted bias

Fig. 6. Same as Fig. 4 with corrected RT products.

a) Frequency distribution of daily rainfall

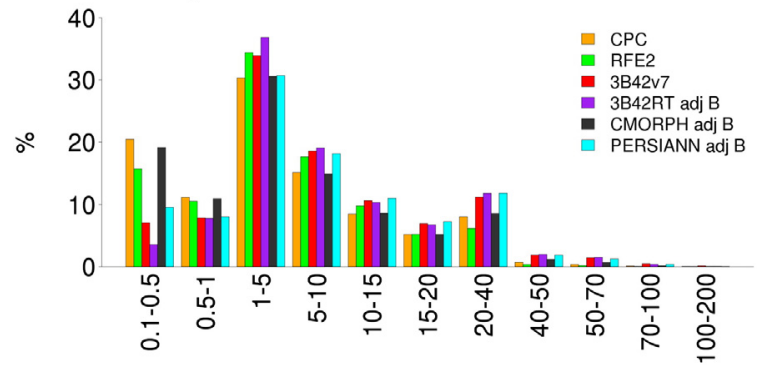

b) Contribution of rain rate classes to season total

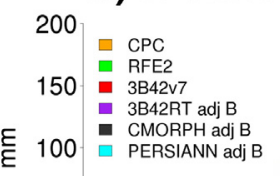

$\begin{array}{ll}100 & \text { 3B42RT adj B } \\ \text { CMORPH adj B } \\ \text { PERSIANN adj B }\end{array}$

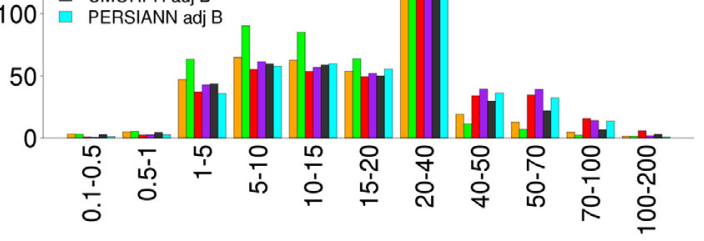

Fig. 7. Same as Fig. 5 with corrected RT products. reservoir $(G)$ (Decharme et al., 2010), a two way flood scheme $(F)$ (Decharme et al., 2008) and a deep aquifer reservoir (Aq) (Pedinotti et al., 2012). This new system results in the following governing equations:

$$
\begin{aligned}
& \frac{\delta G}{\delta t}=\alpha Q_{s b}-Q_{\text {out }}^{G} \\
& \frac{\delta S}{\delta t}=Q_{\text {in }}^{S}+Q_{\text {out }}^{G}+\left(Q_{\text {out }}^{F}-Q_{\text {in }}^{F}\right)-Q_{\text {out }}^{S} \\
& \frac{\delta F}{\delta t}=Q_{\text {in }}^{F}+\left(P_{f}-I_{f}-E_{f}\right)-Q_{\text {out }}^{F} \\
& \frac{\delta A q}{\delta t}=(1-\alpha) Q_{s b}-Q_{\text {out }}^{A q}
\end{aligned}
$$

where $Q_{\text {in }}$ and $Q_{\text {out }}$ represent, respectively, the inflow and the outflow of the relevant reservoir. $\alpha$ is a fixed value (0.75) defining the partition of the deep drainage $(s b)$ going to ground water $(\alpha)$ and aquifer $(1-\alpha)$. Here water going to deep aquifer reservoir does not contribute to the river. $I_{f}$ and $E_{f}$ are respectively the infiltration and the evaporation and $\mathrm{P}_{\mathrm{f}}$ the rainfall, over the flood plain. More details can be found in Pedinotti et al., 2012. The outflow from a river grid cell is defined as:

$Q_{\text {out }}^{S}=\frac{v}{L} S$ with $v=\frac{k}{n_{\text {riv }}} R^{2 / 3} S^{1 / 2}$

where $Q_{\text {out }}$ is the simulated river discharge $\left(\mathrm{m}^{3} \mathrm{~s}^{-1}\right)$, $\mathrm{L}$ is the river length ( $\mathrm{m}), \mathrm{S}$ is the water mass $(\mathrm{kg}), \mathrm{k}$ is a constant equal to 
$1, \mathrm{R}$ is the hydraulic radius ( $\mathrm{m}$ ) and $\mathrm{s}$ is the downstream river height loss per unit length $\left(\mathrm{mm}^{-1}\right)$.

The grid resolution of the model is $0.5^{\circ *} 0.5^{\circ}$ degrees, the time step of ISBA is $10 \mathrm{~min}$, the time step of the input variables is $3 \mathrm{~h}$ and the coupling between ISBA and TRIP is daily.

\subsection{Specific configuration}

Simulating the discharge over the entire Niger basin, including the propagation through the inner delta, has proved to be difficult (Decharme et al., 2011; Pedinotti et al., 2012) because the hydrodynamics inside the delta and its flood plains are not resolved explicitly by the relatively simple flood parameterization used herein. In order to correctly assess the rapid response of the watershed to the monsoon rainfall in the vicinity of Niamey (circle in Fig. 1), bias in the simulation propagated from upstream should be avoided. Therefore, in the current study, a specific set up was adopted in order to examine the hydrological response to the 'local' rainfall: the observed discharge is imposed approximately $350 \mathrm{~km}$ upstream of Niamey (and before the junction with the 3 right bank tributaries) at the station located in the city of Ansongo (Figs. 1 and 8). The numerical experiment is limited to the Niger basin between Ansongo $\left(15^{\circ} 40^{\prime} \mathrm{N}, 0^{\circ} 30^{\prime} \mathrm{E}\right.$, Mali) and Niamey $\left(13^{\circ} 31^{\prime} \mathrm{N}\right.$, $2^{\circ} 6^{\prime} \mathrm{E}$, Niger), including the tree right bank tributaries: Gorouol, Dargol and Sirba.

This configuration is a research version, but could be considered for operational flood prediction. For operational purposes, one could run the model with a daily discharge collected in Ansongo (or, in the future, from satellite altimetry). Some flood models are based solely on relating the discharge in one point with the discharge upstream. The use of ISBA-TRIP accounts for the rainfall-runoff processes on the right bank basins, which contribute to a significant portion of the discharge in Niamey (as seen in Fig. 3).

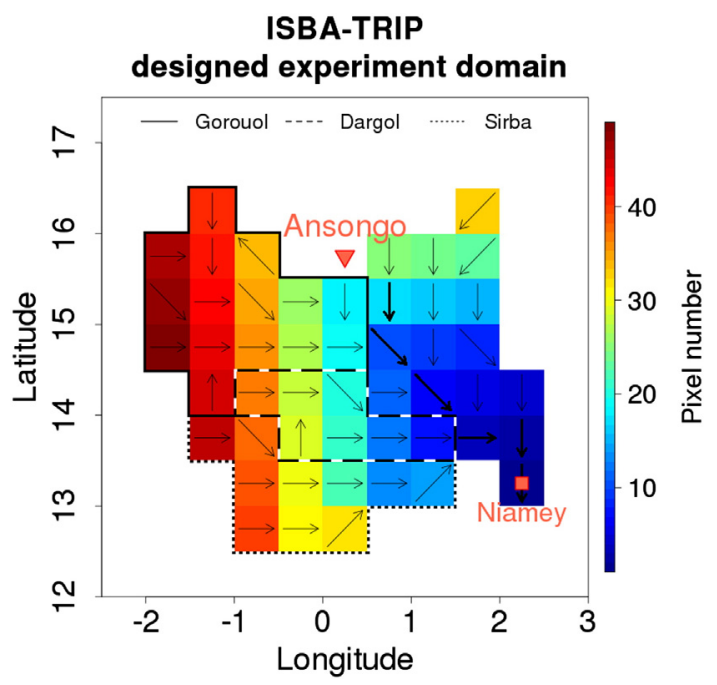

Fig. 8. The area of the Niger basin (between Ansongo and Niamey) considered for the simulation, covering $490.5^{\circ} \times 0.5^{\circ}$ pixels (numbered 1 to 49 with the colour scale). (For interpretation of the references to colour in this figure legend, the reader is referred to the web version of this article.)

\subsubsection{Atmospheric forcing}

Forcing data consists in rainfall (Section 3.1), and atmospheric state variables: air temperature, specific humidity, wind components at $10 \mathrm{~m}$ and surface pressure. For the currents runs, the atmospheric state variables are based on the WATCH Forcing Data methodology applied to ERAInterim data (WFDEI, Weedon et al., 2011). WFDEI provide eight meteorological variables at 3-hourly time steps for global surface at $0.5^{\circ} \times 0.5^{\circ}$ resolution. Note that the WATCH rainfall field is replaced by the products described herein.

A sensitivity test covering a decade (from 2003 to 2012) showed that there is no significant difference, in terms of discharge, between simulations forced with the WFDEI data set or with an inter-annual mean (for all meteorological variables except rainfall), at each time step. As the WFDEI data set was available from 2003 to 2012 only, we used an inter-annual mean to force the LSM ISBA from 2000 to 2013. Note that this low sensitivity of the simulated discharge anomaly to using a climatological forcing is particularly interesting for operational flood forecast perspective, which could be based on an interannual mean atmospheric state value.

\subsubsection{Discharge constraint at Ansongo}

In this special experiment, we forced TRIP at Ansongo with observed discharge at this station. The Niger Basin Authority provided daily discharge from 2000 to 2013.

\subsubsection{Other parameters}

The SURFEX model relies on a simple first-order physical representation of hydrologic processes. The model parameters are derived from the ECOCLIMAP database (Champeaux et al., 2005) and other physiographic information (soil type, topography, etc.). Thus, the model can be used on ungauged basins and/or at the global scale, without calibration. The ISBA-TRIP model is ultimately intended for use in a coupled global climate model (which requires a compromise in terms of the level of complexity and implies a relatively coarse spatial resolution).

For the current simulations, the ISBA parameter values needed for calculating the energy and water surface budget are kept standard as in Pedinotti et al. (2012). Note, however, that certain key hydrological parameters (such as those controlling sub-grid runoff or river flow) can be adjusted for a specific case or basin application. The default large scale parameter values have been determined using simple empirical and geomorphological relationships in order to apply the ISBA-TRIP model at the global scale, thus smaller or basin-specific errors are to be expected. After some sensitivity studies, an adjustment of the Manning coefficient ( $n_{\text {riv }}$ in TRIP; Eq. (4)) was done over the study area. The initial value of this parameter was 0.065 for the Niger river between Ansongo and Niamey, and around 0.095 over the other parts of the drainage area. This resulted in very 'slow' or flattened simulated discharge. In the current study, a spatially constant value of 0.035 is prescribed over the entire area. This value is consistent with the range of values reported for large rivers (Maidment, 1992) and described in the literature (Chow, 1964; Gray, 1972). 


\section{Results}

\subsection{Simulated discharge}

The discharge simulated at the Niamey station using the 9 different rainfall forcing is compared to the observations in Fig. 9. The Nash-Sutcliffe Efficiency coefficient (NSE) (Nash and Sutcliffe, 1970; Krause et al., 2005) is calculated as:

$N S E=1-\frac{\sum_{i=1}^{n}\left[\left(E_{i}-O_{i}\right)^{2}\right]}{\sum_{i=1}^{n}\left[\left(\bar{O}-O_{i}\right)^{2}\right]}$

where $O$ is the observed data series, and $E$ the estimated data series.
The agreement between the observations and the simulations forced by any of the 3 products that ingest gauge information (CPC, RFE2 and 3B42v7) is high (top plot in Fig. 9). The NSE is slightly higher for the 3B42v7 based simulation. The zoom on the first flood shown below (Fig. 10) reveals that the simulation based on this forcing is best at reproducing the fast variations of the discharge. This is attributable to the high temporal resolution ( $3 \mathrm{~h}$ ) of this product and also due to its ability to reproduce the spatial patterns (Guilloteau et al., accepted for publication) in contrast with the tendency of RFE2 to smooth the rainfall patterns (Section 3.2.1 and Figs. 4 and 5). As expected, the simulations based on the RT estimators produce strong positive biases in the discharge (middle plot in Fig. 9). The RT products bias-adjusted with the simple probability matching method provide much better results (bottom plot in Fig. 9). The best NSE is obtained for the bias-

Simulated and observed discharge in Niamey for 2000-2013 period
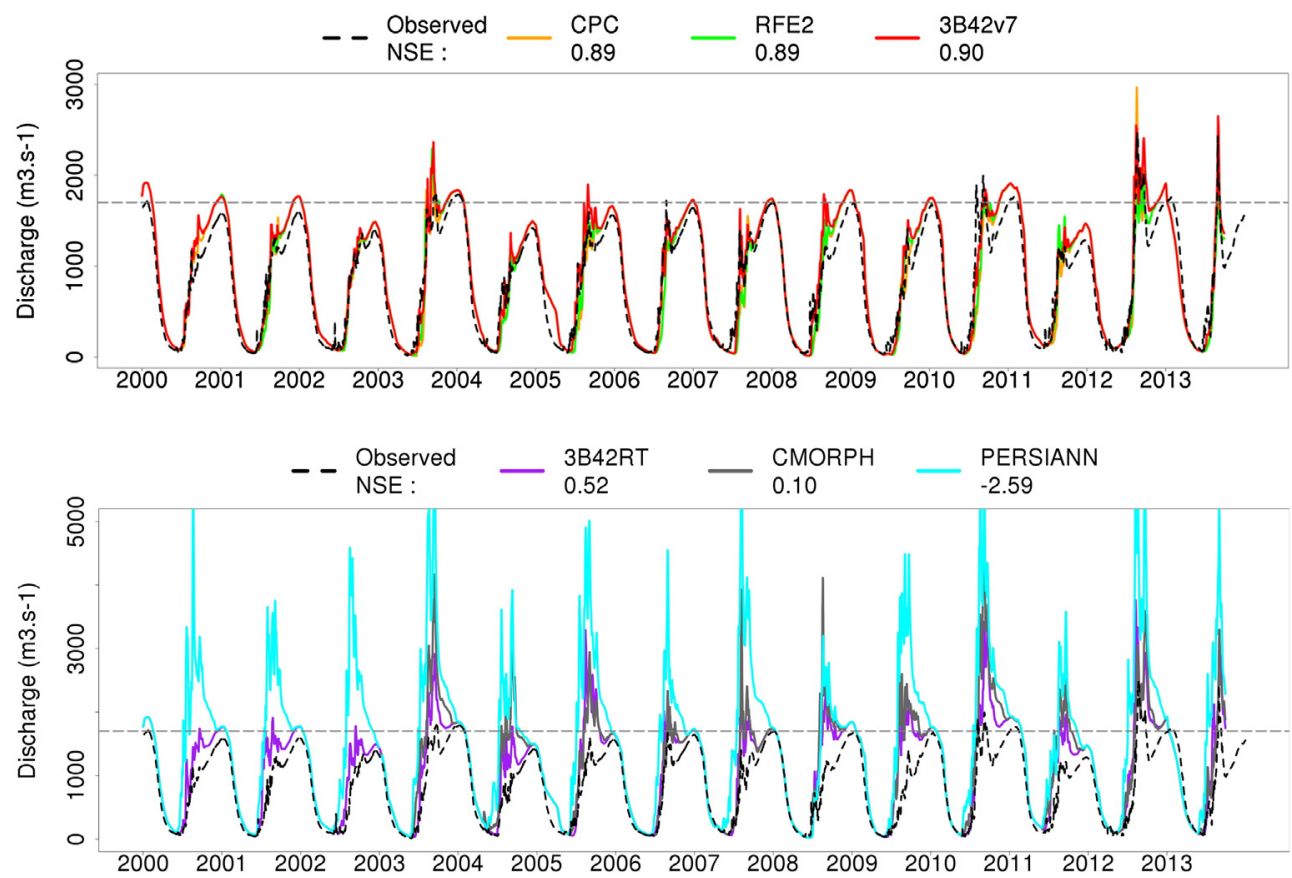

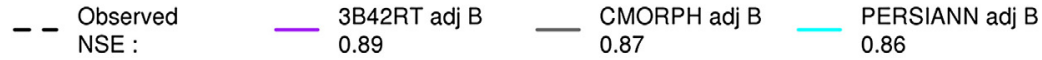

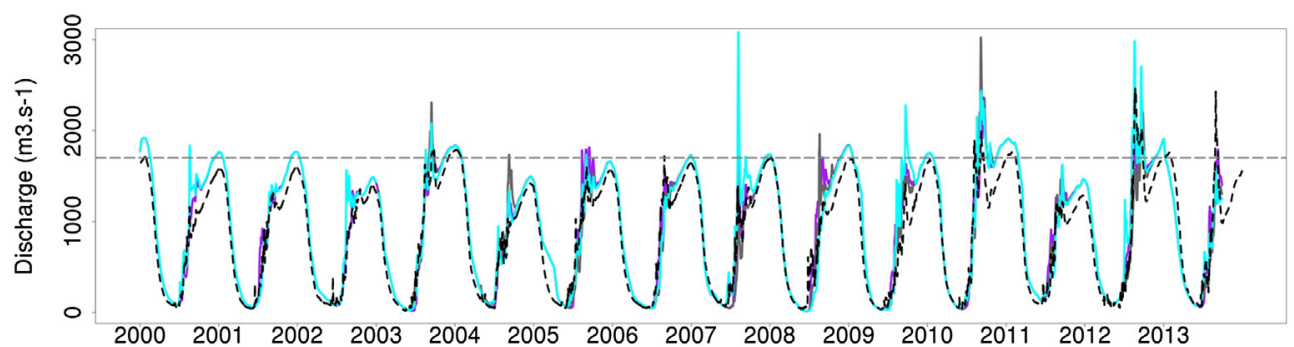

Fig. 9. The observed (black dash) and ISBA-TRIP simulated discharge at Niamey for the indicated rain forcing. Top: CPC, RFE2, 3B42 v7. Middle: 3B42RT, CMORPH and PERSIANN. Bottom: the 3 bias-adjusted RT products. The horizontal grey dashed line refers to the $1700 \mathrm{~m}^{3} \mathrm{~s}^{-1}$ value that defines the flood threshold. The NSEs (Eq. (5)) are indicated on the plots. 
adjusted version of 3B42RT, which has the same skill as the gauge fed products.

\subsection{A closer look to flood events dynamics}

Figs. 10 and 11 illustrate the genesis of the 2012 and 2010 floods and the rain that caused it, using various rainfall products. The time evolution and spatial distribution of rainfall within the forty-nine pixels is shown in the uppermost panels. The $\mathrm{Y}$ axis is the pixel number (as in Fig. 8); the larger the number, the further away from Niamey the pixel is. The rainfall is given as the daily amount of rainfall (in $\mathrm{mm}$ ) per pixel. The bottom panels depict, with the same $\mathrm{x}$ axis, the daily time series of mean rainfall over the domain and the observed and simulated discharge.

In 2012 (Fig. 10), the two successive rises of the discharge are associated with at least 2 major events that occurred in August (August 3rd and August 13th for 3B42v7 Fig. 10c). These rainfall events are estimated as the highest rainy days of the period by all products (the 99th percentile is reached); however the absolute intensity of these events vary among the products.

RFE2, CPC and 3B42v7 have similar values of the cumulated rainfall over the period and the domain (Section 3.2) because they both ingest gauge information. Further examination of the two uppermost panels in Fig. 10b and c reveals the differences in the way the rainfall is distributed, in time and space. It also shows the consequences on the simulated hydrological response. RFE2 spreads the rain smoothly over the domain and the rain rates are quite low, thus limiting the runoff and subsequent discharge. The $3 \mathrm{~B} 42 \mathrm{v} 7$ and CPC simulations follow the observed rise in the observed discharge much better. The dashed lines in the bottom panels show the inter-annual mean of the discharge and confirm that the agreement between the 3B42v7 forced simulation and the observation is steady. The underestimation of the discharge with RFE2 is a stable feature (and in accordance to what was found by Gosset et al. (2013) in Benin).

As seen in Fig. 9, the positive bias in the RT products propagates as a positive bias in the discharge. The positive shift of the frequency distribution (Fig. 7b) enhances this bias (Thiemig et al., 2012; Gosset et al., 2013). Bias-adjusting the products improves the results. The best simulation is obtained with the bias-adjusted version of 3B42RT (Fig. 10d). The response to the first intense event is well reproduced, however, the bias-adjustment reduces too much the effect of the second event. As mentioned in Section 3.2.2, CMORPH bias in 2012 is low compared to the other years and the correction overcompensates the bias leading to an underestimation of the outflow (Fig. 10e). PERSIANN (Fig. 10f) is the most biased and the rise in the discharge is both too high and much too early. The bias-adjustment improves the simulation, but the early rise of the discharge is not eliminated and the positive bias is lower but persists.

Similar tendencies in the differences between the products and their consequences on the hydrological response may be drawn from the 2003, 2006 and 2013 sequence (not shown).

The 2010 flood is presented in Fig. 11, for the 3B42v7 forcing only as an illustrative example of the limits of the hydrological simulations. Between July 19th and August 19th, the observed discharge increases sharply, but no product detects any strong rainfall and accordingly the simulation misses this increase and remains close to the inter-annual mean. $A B N$ reported a dyke rupture which could explain the disagreement between the discharge observations and the rainfall.

The time series in Figs. 10 and 11 point out that between the rainfall events and the successive rises in the discharge that build the Niamey first flood, the time lag is about 2 to 5 days. This implies that rainfall products need to be available with a delay of 1 to 2 days in order to be useful for operational purposes.

\subsection{Flood prediction}

As mentioned previously, the ABN considers that the critical outflow that leads to flood is $1700 \mathrm{~m}^{3} \mathrm{~s}^{-1}$. Based on the analysis of the discharge time series, this threshold is equivalent to the 95th percentile, over the 2000-2013 period. This section discusses the ability of the products plus model to predict a period of time when the $1700 \mathrm{~m}^{3} \mathrm{~s}^{-1}$ level or the 95 th percentile in the discharge are exceeded.

Fig. 12 summarizes the periods per year when the observed and simulated discharges exceeded the $1700 \mathrm{~m}^{3} \mathrm{~s}^{-1}$ threshold. The agreement between the observations and the simulations forced by CPC and the gauge-adjusted products - RFE2 and 3B42v7 - is quite good. 2003, 2012 and 2013 are correctly detected as flooded for at least one day by these 3 simulations. They all miss the short flood in 2006. CPC misses also the 2010 flood and 3B42v7 falsely detects floods in 2005 and 2008. As expected from the previous sections, the simulations based on the RT products generate a lot of spurious floods because of the excess of rainfall. The 3B42RT and PERSIANN based simulations generate floods every year. The results are improved with the bias-adjusted RT products; however numerous false alarms remain ( 3 for 3B42RT and PERSIANN and 1 for CMORPH) and the misses increase (CMORPH and PERSIAN miss the 2013 flood).

In Fig. 13 a similar analysis is performed using the 95th percentile of each discharge series as a threshold (the line of observation is thus identical in Figs. 12 and 13). 2003, 2010, 2012 and 2013 stand out as flooded years with a good agreement between the simulations (except in 2013 for bias-adjusted CMORPH and PERSIANN). The agreement between the observations and the simulations, in terms of detecting the occurrence of years with at least one flood day, is improved : (i) for the gaugeadjusted product a slight improvement is found for 3B42v7, only 1 year with false alarm (ii) for the RT products, the improvement is spectacular. The number of years with a falsely detected flood is much reduced (2 years for 3B42RT and CMORPH and 4 with PERSIANN).

This suggests that an ensemble prediction based on several RT estimators (and ideally sub-ensembles based on the uncertainty, for each estimator) would provide some skill for detecting years with flood risk. A more challenging task however is to predict the duration and timing of the flood, within the season.

In Tables 5 and 6, the skill of the simulations is analysed in terms of probability of detection (POD) and false alarm rate (FAR) for individual flood days, based on the 95th percentile. In addition to the classical POD (or FAR) calculated by comparing each observed flood with the simulated discharge on the same day, we also allowed a temporal tolerance. The detection is considered valid if one flood day is predicted within a time window of plus/minus $\mathrm{N}$ days. This tolerance window allows verifying if the prediction system (rain forcing + model) 
a)
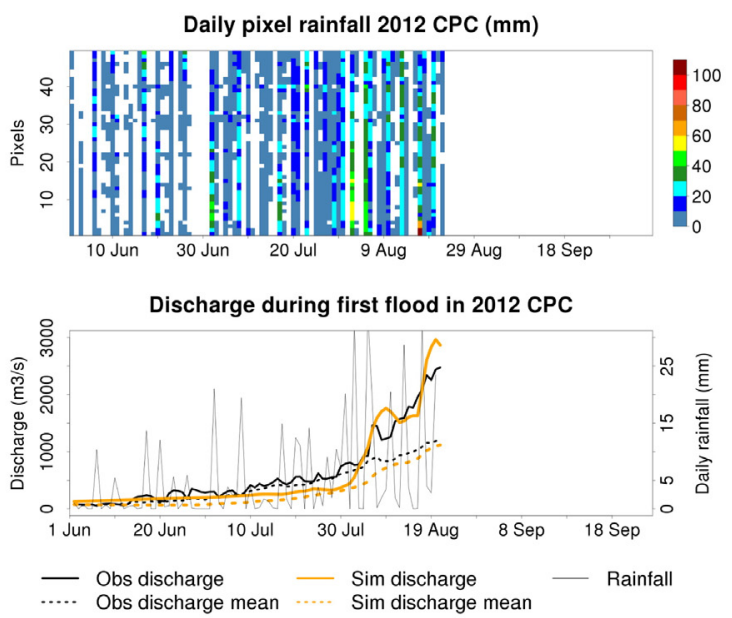

c)
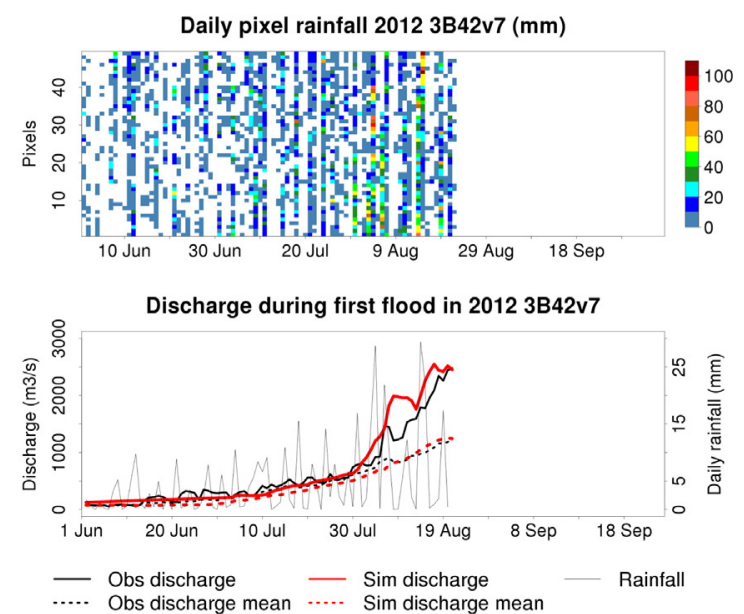

e)
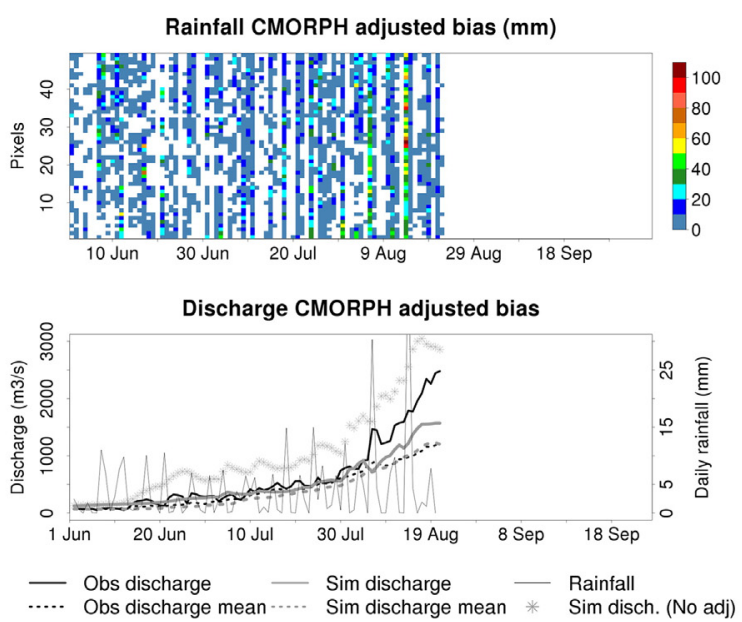

b)
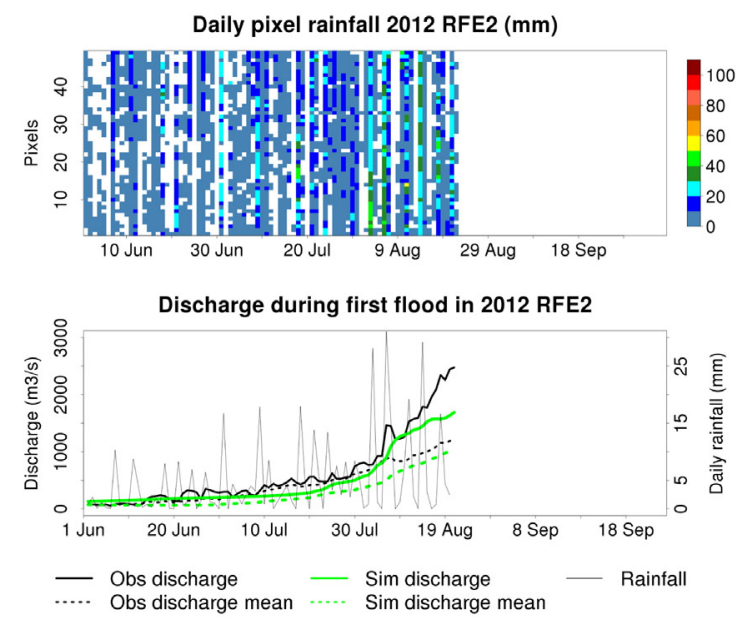

d)
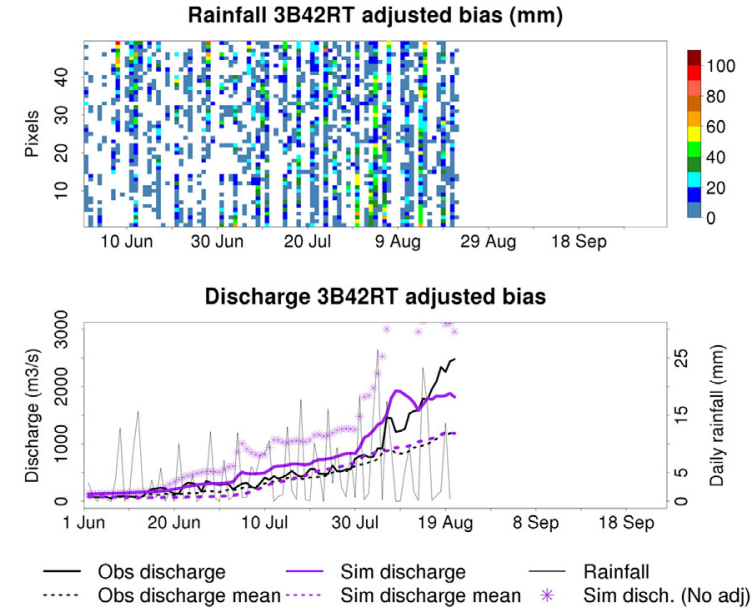

f)
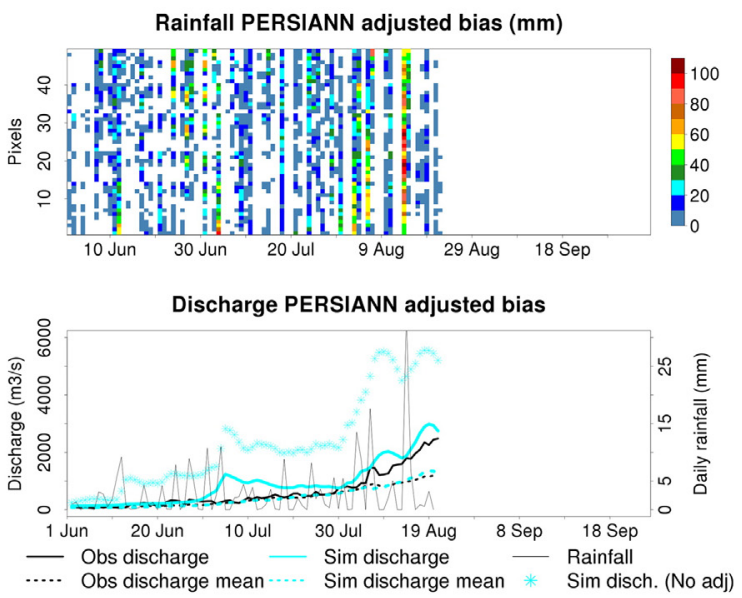

Fig. 10. Time evolution of the rainfall over the region (i.e., the 49 pixels numbered in Fig. 8) and the observed and simulated discharge between the 1 st of June and the observed first peak, in 2012. Top: y axis : pixel number (1 to 49); $x$ axis: day of year; the colour represents the amount of rainfall (in mm) for each pixel and day. Bottom: Time evolution of the mean rainfall over the zone (light grey), the observed discharge (black) and its inter-annual mean (back dashes), the simulated discharge (colour) and its inter-annual mean (coloured dashes); for RT products stars represent the simulated discharge before bias-adjustment of the forcing. (For interpretation of the references to colour in this figure legend, the reader is referred to the web version of this article.) 

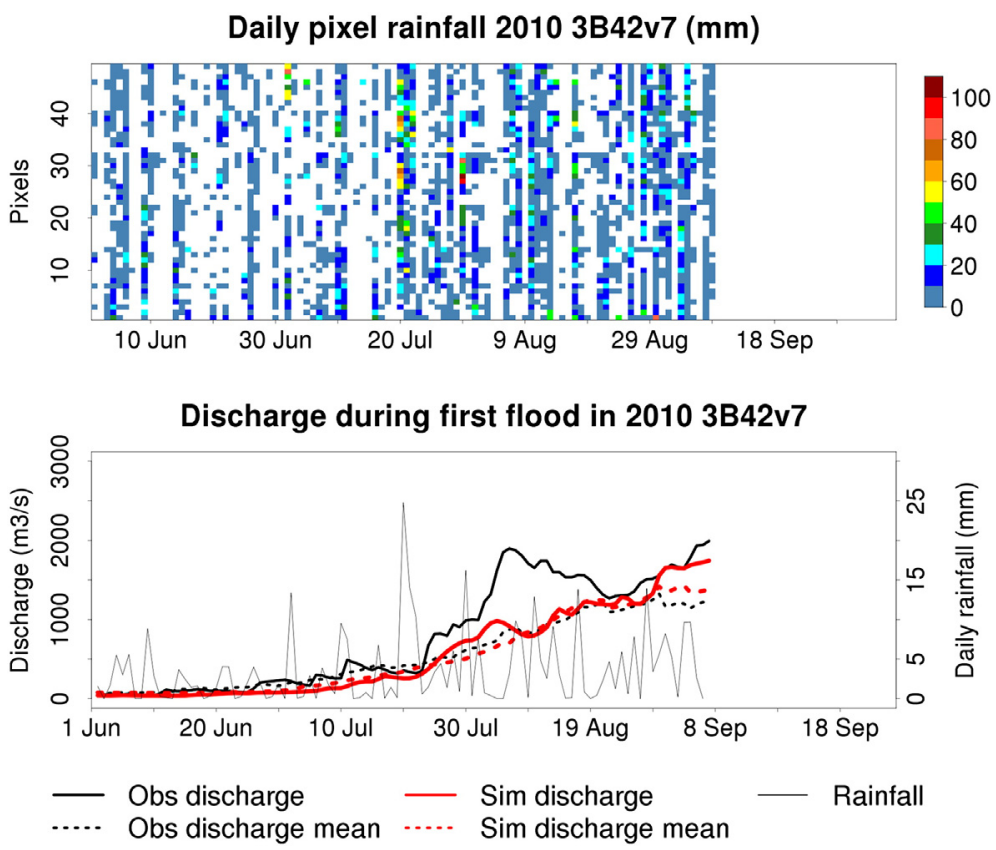

Fig. 11. Same as Fig. 10 for 3B42v7 in 2010.

diagnoses a flood event but not its exact timing. The relatively coarse resolution of the model, the simplified representation of the runoff processes, the uncertainty in the rain forcing may cause slight shifts in the timing of the hydrological response. Fig. 9 shows indeed that the daily scale details in the discharge are different for the various simulations and for the observation. Tables 5 and 6 report the results for the classical POD and FAR, and with tolerance windows of 1, 2, 3 and 5 days.

With the simulations based on CPC and 3B42v7, the POD is $60 \%$, and rises at $71 \%$ for a time tolerance of 2 days or more. For these two simulations the FAR is initially $33 \%$ and drops to $22 \%$ and below for a 2 day tolerance. The CPC and 3B42v7 based simulations are in very good agreement, despite the differences between these two products in terms of number, intensity and spatial extension of the rainy days (Fig. 4). This may be due to the type of model (global LSM) and relative coarse grid resolution used, which reduces the sensitivity to the rain forcing. The scores are however lower with RFE2, which tends to generate more false alarm, in agreement with its tendency to overestimate the number of rainy days (Fig. 4).

The scores are substantially lower for the RT products. A tolerance window of 2 days is needed to reach a POD close to $60 \%$ and FAR close to $30 \%$. The POD obtained with the biasadjusted products is similar than for the raw RT. The best performance is for 3B42RT and PERSIANN, while the POD is low for CMORPH. With a tolerance of 5 days the POD for the best RT based simulations is $67 \%$ and the FAR below $25 \%$.

\subsection{Inter-annual variability}

The previous sections have established that the satellite based simulations have some skill in predicting floods, even if the product has biases, as long as the analysis is based on a relative level (percentile) rather than the absolute level. An important consideration however is the stability of the rain products performance over the years used to calculate the percentiles. If the bias changes drastically from one year to another (due to a change in one of the rainfall algorithm parameters, for instance) it may lead to an erroneous detection of the flood risk because an anomaly appears in the series. Fig. 14 analyses the inter-annual variability of the peak discharge (first flood), and the consistency between the simulations and the observations. We focus on the relative variation. To do so, the series of 14 (i.e.,; 2000-2013) annual maximum discharges are standardized (i.e., subtraction of the inter-annual mean and division by the standard deviation) and we study the positive or negative anomalies : for any variable $x$, defined over the period as a time series of observed $x_{i}$, the anomaly of $x$ for a given hydrological year $i$ is :

$A_{x i}=\frac{x_{i}-\bar{x}_{i}}{\sigma_{x i}}$

where $\bar{x}_{i}$ is the inter-annual mean, and $\sigma_{x i}$ is the standard deviation of the 14 member sample of $x$.

The correlations between the series of simulated and observed peak discharge anomalies are indicated on each plot in Fig. 14. Given the small number of points (and the fact that the hydrological response to rainfall is non-linear), we calculated both the classical Pearson's linear correlation coefficient (Pearson, 1896) and the Spearman's rank correlation coefficient (Spearman, 1904). To verify the significance of the agreement between series, and the differences between products, these correlations were re-calculated 13 times by omitting each year in turn. The correlations drop slightly when 2012 is omitted (there is a mean decrease of 0.07 for both coefficients) but the tendencies observed are otherwise very stable. For the series used in Fig. 14, the value of the simulated 


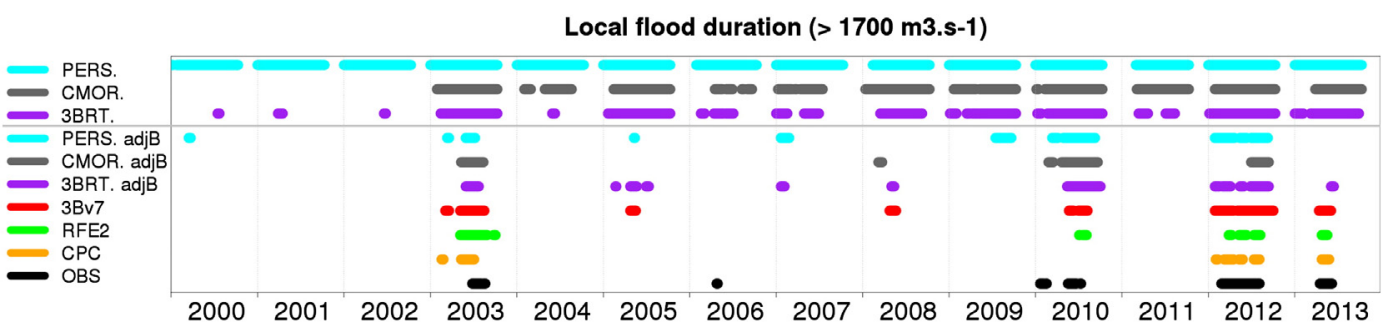

Fig. 12. Period when the observed (black) or simulated (colours) discharge is above $1700 \mathrm{~m}^{3} \mathrm{~s}^{-1}$. For each year the ASO period is shown.

peak discharge on a given year is taken on the date of the observed peak. However the results are very similar if the discharge anomaly is calculated, for each series, on the day of their relative maximum. For the latter (not shown) the correlations are slightly higher than in Fig. 14 for 3B42RT, CMORPH, RFE and CPC, and slightly lower for 3B42v7, PERSIANN. The relative merits of the products stay the same.

The agreement between the simulated and observed discharge peak anomalies is good for most simulations. The only exception is CMORPH, and this is in direct relation with the year to year variability of the product bias mentioned in Section 3.2. The best agreement is between the 3B42v7 forced simulation and the observations (correlation above 0.9). This can be attributed to the fact that this product is gauge bias-adjusted, and it also performs well in terms of intensity, space and time distribution of the rainfall patterns (Guilloteau et al., accepted for publication). The second best is the simulation based on the CPC product (despite the low number of gauges available) closely followed by the 3B42RT simulation. It is noteworthy that the results are not improved (and even slightly degraded) when using the bias-adjusted rainfall products. Again, it comes from the use of the relative variations of the discharge, which provide a useful information even in case of strong bias in the rain forcing, as long as the latter is steady over the years.

The various analysis from Section 5 suggest that, when using RT rainfall products that have (positive) biases, analyzing the model output in relative terms (percentile, anomaly) provides slightly more skill than bias-adjusting the products themselves. This result is model dependant. A hydrological model with finer resolution and a different representation of the rainfall-runoff relation may lead to a different conclusion. Also the bias-adjustment technique tested here is very simple and other methods should be tested.

\section{Conclusion}

This work is the first analysis of the recent enhancement of first or 'red' floods events in Niamey based on satellite rainfall observations. It demonstrates the usefulness of state of the art rainfall products to monitor the genesis of these events and predict their occurrence.

Two conditions are necessary to predict floods with a hydrological model forced with a rainfall satellite product: (i) the product must detect the relatively high rainfall accumulations that lead to flooding and (ii) the model must be able to transform the rainfall excess into a discharge exceeding a critical level. The critical level may be absolute or relative.

In this study, the large scale ISBA-TRIP LSM-routing model, working at a relatively coarse spatial resolution $\left(0.5^{\circ}\right)$ is used with no calibration/adjustment to account for the hydrological specificities of the Niger right rim basins. The model is forced with six rainfall products, three of them ingest rain gauge information, and the three others are based on satellite information only. The comparison of the rainfall products over the $125,000 \mathrm{~km}^{2}$ large study area, in the Sahel, reveals some substantial differences. The products based on satellite only - and which are available with a short delay, thus referred as RT - have a common tendency to produce more rain than the gauges (and for PERSIANN, much more). The rainfall intensity distribution and the spatial and temporal patterns differ; even among the products that ingest gauge data and have the same seasonal accumulations.

The discharges simulated with the 6 products as forcing have been compared with the observations at the Niamey station for the period 2000-2013. A bias-adjusted version of the RT

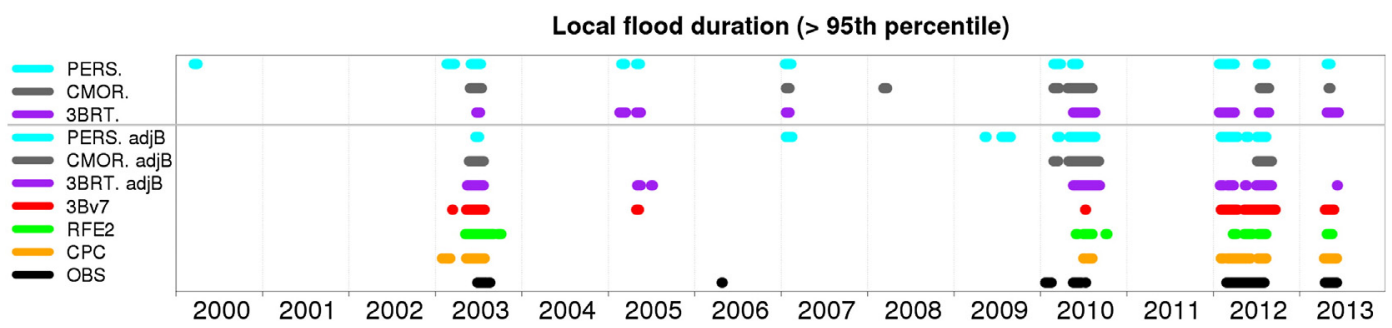

Fig. 13. Period when the observed (black) or simulated (colours) discharge is above the 95th percentile. For each year the ASO period is shown. (For interpretation of the references to colour in this figure legend, the reader is referred to the web version of this article.) 
Table 5

Probability of detection (POD) and POD with different temporal tolerance windows (plus or minus 1, 2, 3 and 5 days).

\begin{tabular}{llllll}
\hline & POD & Window 1 day & 2 days & 3 days & 5 days \\
\hline CPC & 0.61 & 0.66 & 0.71 & 0.74 & 0.77 \\
RFE2 & 0.53 & 0.64 & 0.73 & 0.80 & 0.83 \\
3B42v7 & 0.60 & 0.66 & 0.71 & 0.74 & 0.76 \\
3B42RT & 0.47 & 0.53 & 0.57 & 0.63 & 0.69 \\
CMORPH & 0.30 & 0.35 & 0.41 & 0.45 & 0.50 \\
PERSIANN & 0.36 & 0.44 & 0.50 & 0.57 & 0.69 \\
3B42RT adj B & 0.43 & 0.50 & 0.57 & 0.61 & 0.67 \\
CMORPH adj B & 0.32 & 0.35 & 0.39 & 0.42 & 0.47 \\
PERSIANN adj B & 0.46 & 0.52 & 0.58 & 0.64 & 0.67 \\
\hline
\end{tabular}

products, based on a probability matching technique with 3B42v7 as a reference was also tested.

- The comparison of the simulated/observed discharge time series reveals a good global agreement (on the basis of the Nash Sutcliff Efficiency or NSE, above 0.89) when the model is forced by any of the products that ingest gauges (CPC, RFE2, 3B42v7). The NSE drops when the RT products are used, because of the excess rainfall they generate. The NSE is high (above 0.85) for the bias-adjusted RT products.

The ability of the simulations to predict the flood risk has been analysed with several diagnostics and at different scales.

- The detection of the discharge reaching a relative threshold (here, the $95 \%$ percentile) is a better diagnostic than detecting the absolute level $\left(1700 \mathrm{~m}^{3} \mathrm{~s}^{-1}\right)$. The former diagnostic reduces the impact of the products error propagation in the hydrological model. With the tested products and model, the analysis of the 95th percentile is sufficient and bias-adjustment does not provide a better diagnostic of the flood.

- The simulations are able to detect the years when a flood occurred; but some of this skill is lost (in 2013) when the RT product are unbiased. The simulations based on the RT products, diagnose floods in 2 of the 'un-flooded' years.

- The ability of the simulations to diagnose that a given day is or not flooded, was tested with and without a temporal tolerance window. The best scores are obtained with 3B42v7 and CPC, with a POD of $60 \%$ (FAR of 30\%), and with a tolerance of 2 days a POD above 70\% (and FAR 20\%). For the RT products the best results are obtained for 3B42RT with POD above 60\% and FAR below $30 \%$, with a tolerance of 3 days; then, PERSIANN is also satisfactory.

Table 6

False alarm rate (FAR) and FAR with different temporal tolerance windows (1, 2, 3 and 5 days).

\begin{tabular}{llllll}
\hline & FAR & Window 1 day & 2 days & 3 days & 5 days \\
\hline CPC & 0.32 & 0.25 & 0.20 & 0.17 & 0.12 \\
RFE2 & 0.39 & 0.31 & 0.26 & 0.22 & 0.15 \\
3B42v7 & 0.33 & 0.28 & 0.22 & 0.17 & 0.12 \\
3B42RT & 0.44 & 0.34 & 0.28 & 0.23 & 0.16 \\
CMORPH & 0.55 & 0.38 & 0.29 & 0.21 & 0.08 \\
PERSIANN & 0.54 & 0.43 & 0.33 & 0.25 & 0.16 \\
3B42RT adj B & 0.49 & 0.38 & 0.29 & 0.26 & 0.22 \\
CMORPH adj B & 0.53 & 0.38 & 0.31 & 0.26 & 0.19 \\
PERSIANN adj B & 0.45 & 0.32 & 0.24 & 0.23 & 0.18 \\
\hline
\end{tabular}

- The agreement between the simulations and the observations, in detecting the relative amplitude of the annual peak discharge (inter-annual anomalies) is very good (correlation above 0.9 for 3B42v7; 0.8 for CPC and 3B42RT) except for CMORPH, because of the year to year variability of its bias.

These results demonstrate that the state of the art satellite rainfall products - even RT if used with caution - can be quantitatively useful for diagnosing the flood risk in Niamey. The work also highlights the benefit of rainfall estimators with stable performances over the years for hydrological applications or any early warning system. Even though RT products are not meant for studying inter-annual variability (products that combine more information are better suited from a climatological view point), their use in an early warning system requires steady statistics in order to detect extreme events.

A deeper analysis of the hydrological processes is needed to further improve the hydrological modelling and fully exploit the spatial and temporal information provided by the satellite rainfall products. More work is planned to study the sensitivity of the prediction chain to various parameters: the model spatial resolution, the soil infiltration properties - which have been shown to vary in the recent years because of changes in the land use (Albergel, 1987; Amani and Nguetora, 2002; Mahé et al., 2003, 2005; Leblanc et al., 2008; Mahé and Paturel, 2009; Amogu et al., 2010; Gardelle et al., 2010; Descroix et al., 2009, 2012), the parameterization of the runoff production and the need to better account for the Hortonian nature of runoff over this area (Descroix et al., 2009, 2012; Amogu et al., 2010). Testing other hydrological models is also under consideration. Future development will also include working with ensemble inputs in order to account for uncertainties in the rain forcing (Hossain et al., 2004; Hong et al., 2006; Moradkhani et al., 2006).

These results show that a prediction tool based on monitoring both (i) the early rise in the slow variation of the Niger outflow upstream Niamey and (ii) the 'local' rainfall that cause the rapid rise of the first peak, would improve the operational monitoring of the Niger River floods in Niamey. Monitoring the outflow before Niamey is currently achieved by the Niger Basin Authority $(A B N)$ by in situ gauging; in the future it could be based on high resolution altimetry, with data provided by the future SWOT (Surface Water Ocean Topography) satellite. The Global Precipitation Mission (GPM) era with its enhanced sampling of rainfall by a micro-wave constellation (Hou et al., 2013) especially in the Tropics thanks to MeghaTropiques (Chambon et al., 2012), is expected to provide RT rainfall products with higher resolution and better accuracy. These should improve the study of 'local' hydrological phenomena such as the Niamey first flood or other hydrological extremes.

\section{Acknowledgements}

We warmly thank Luc Descroix for his advices on this work, and the Niger Basin Authority (ABN), for providing the Niger River discharge data and for their collaboration. We would like also to thank all the teams that provided the various rainfall data sets online. This work as been co-funded by the French 
CPC

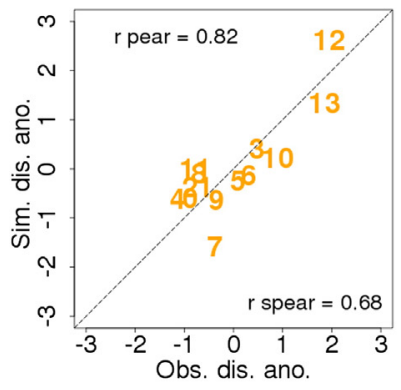

RFE2

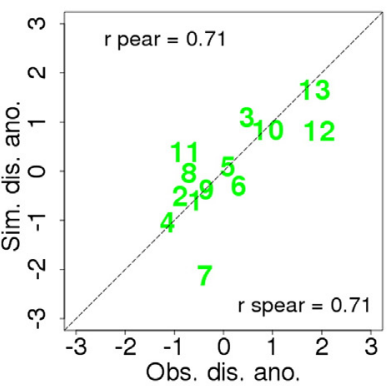

3B $42 v 7$

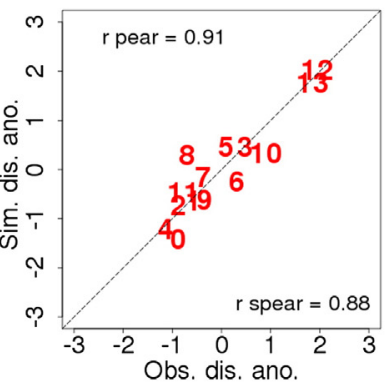

3B42RT

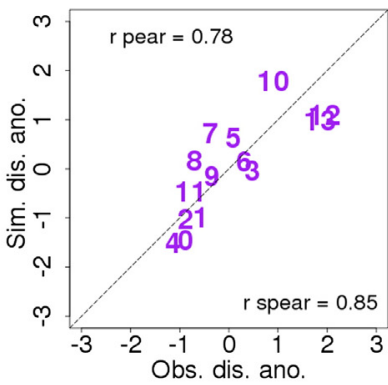

CMORPH

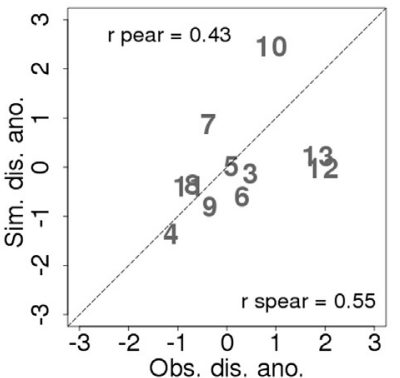

PERSIANN

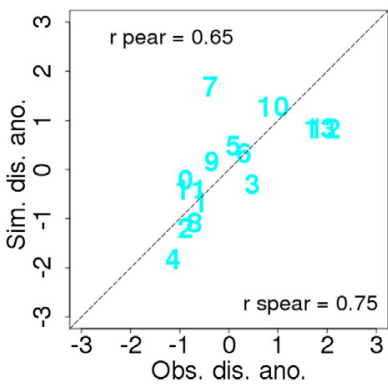

3B42RT adjusted bias

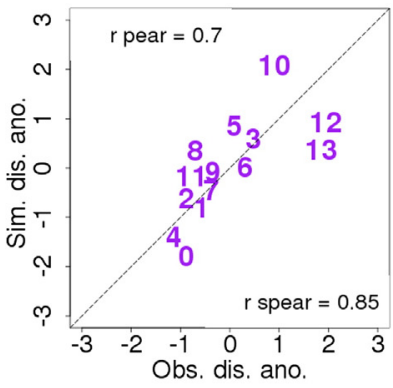

CMORPH adjusted bias

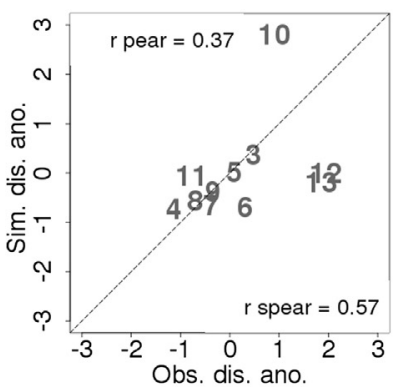

PERSIANN adjusted bias

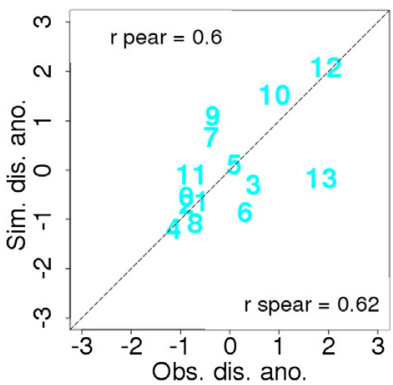

Fig. 14. For each tested rainfall product, and the corrected version of the 3 RT products: scatter plots of the anomaly in the simulated peak discharge versus the anomaly in the observed peak discharge. The last 2 digits of the year are indicated for each dot (i.e., $12=2012$ ).

Centre National d'Etudes spatiales (CNES) and the Midi-Pyrénées region.

\section{References}

ACTED, OXFAM, République du Niger, UNICEF, 2012. Enquête auprès des ménages sinistrés par les inondations à Niamey. République du Niger

Albergel, J., 1987. Sécheresse, désertification et ressources en eau de surface application aux petits bassins du Burkina Faso. The Influence of Climate Change and Climatic Variability on the Hydrologic Regime and Water Resources, Vancouver. IAHS Publication 168, pp. 355-365.

Ali, A., Amani, A., Diedhiou, A., Lebel, T., 2005. Rainfall estimation in the Sahel. Part II: evaluation of rain gauge networks in the CILSS countries and objective intercomparison of rainfall products. J. Appl. Meteorol. 44, 1707-1722.

Alpert, P., 2002. The paradoxical increase of Mediterranean extreme daily rainfall in spite of decrease in total values. Geophys. Res. Lett. 29, 1-4

Amani, A., Nguetora, M., 2002. Evidence d'une modification du régime hydrologique du fleuve Niger à Niamey. 4th FRIEND 2002 - Regional Hydrology: Bridging the Gap between Research and Practice, Cape Town, South Africa. IAHS Publication 274, pp. 449-456.

Amogu, O., Descroix, L., Yéro, K.S., Le Breton, E., Mamadou, I., Ali, A., Vischel, T., Bader, J.-C., Moussa, I.B., Gautier, E., Boubkraoui, S., Belleudy, P., 2010.
Increasing river flows in the Sahel? Water 2, 170-199. http://dx.doi.org/10. 3390/w2020170.

Andersen, I., Dione, O., Jarosewich-Holder, M., Olivry, J.C., 2005. The Niger River Basin: A Vision for Sustainable Management. The International Bank for Reconstruction and Development / The World Bank.

Artan, G., Gadain, H., Smith, J.L., Asante, K., Bandaragoda, C.J., Verdin, J.P., 2007. Adequacy of satellite derived rainfall data for stream flow modeling. Nat. Hazards 43, 167-185. http://dx.doi.org/10.1007/s11069-007-9121-6.

Berne, A., Krajewski, W.F., 2012. Radar for hydrology: unfulfilled promise or unrecognized potential? Adv. Water Resour. http://dx.doi.org/10.1016/j. advwatres.2012.05.005.

Bitew, M.M., Gebremichael, M., 2011. Evaluation of satellite rainfall products through hydrologic simulation in a fully distributed hydrologic model. Water Resour. Res. 47, W06526. http://dx.doi.org/10.1029/ 2010 WR009917.

Boone, A., Calvet, J.C., Noilhan, J., 1999. Inclusion of a third soil layer in a landsurface scheme using the force-restore method. J. Appl. Meteorol. 38, 1611-1630.

Briquet, J.P., Mahé, G., Bamba, F., Olivry, J.C., 1996. Changements climatiques recents et modification du regime hydrologique du fleuve Niger Koulikoro (Mali) in: L’hydrologie Tropicale. Géoscience et Outil Pour Le Développement. IAHS PUBLICATION; Paris, pp. 157-166.

Chambon, P., Roca, R., Jobard, I., Aublanc, J., 2012. TAPEER-BRAIN PRODUCT algorithm theoretical basis document level 4. Megha-Tropiques Technical Memorandum. 
Champeaux, J.L., Masson, V., Chauvin, F., 2005. ECOCLIMAP: a global database of land surface parameters at $1 \mathrm{~km}$ resolution. Meteorol. Appl. 12, 29-32. http://dx.doi.org/10.1017/S1350482705001519.

Chow, V.T., 1964. Handbook of Applied Hydrology. McGraw-Hill Book Company, Inc. (Section 7, VIII).

Decharme, B., Douville, H., 2005. Introduction of a sub-grid hydrology in the ISBA land surface model. Clim. Dyn. 26, 65-78. http://dx.doi.org/10.1007/ s00382-005-0059-7.

Decharme, B., Douville, H., Boone, A., Habets, F., Noilhan, J., 2006. Impact of an exponential profile of saturated hydraulic conductivity within the ISBA LSM: simulations over the Rhône basin. J. Hydrometeorol. 7, 61-80.

Decharme, B., Douville, H., Prigent, C., Papa, F., Aires, F., 2008. A new river flooding scheme for global climate applications: off-line evaluation over South America. J. Geophys. Res. 113, D11110. http://dx.doi.org/10.1029/ 2007JD009376.

Decharme, B., Alkama, R., Douville, H., Becker, M., Cazenave, A., 2010. Global evaluation of the ISBA-TRIP continental hydrological system. Part II: uncertainties in river routing simulation related to flow velocity and groundwater storage. J. Hydrometeorol. 11, 601-617. http://dx.doi.org/10. 1175/2010JHM1212.1.

Decharme, B., Alkama, R., Papa, F., Faroux, S., Douville, H., Prigent, C., 2011. Global off-line evaluation of the ISBA-TRIP flood model. Clim. Dyn. 38, 1389-1412. http://dx.doi.org/10.1007/s00382-011-1054-9.

Descroix, L., Mahé, G., Lebel, T., Favreau, G., Galle, S., Gautier, E., Olivry, J.-C., Albergel, J., Amogu, O., Cappelaere, B., Dessouassi, R., Diedhiou, A., Le Breton, E., Mamadou, I., Sighomnou, D., 2009. Spatio-temporal variability of hydrological regimes around the boundaries between Sahelian and Sudanian areas of West Africa: A synthesis. J. Hydrol. 375, 90-102. http:// dx.doi.org/10.1016/j.jhydrol.2008.12.012.

Descroix, L., Genthon, P., Amogu, O., Rajot, J.-L., Sighomnou, D., Vauclin, M., 2012. Change in Sahelian Rivers hydrograph: the case of recent red floods of the Niger River in the Niamey region. Glob. Planet. Chang. 98-99, 18-30. http://dx.doi.org/10.1016/j.gloplacha.2012.07.009.

Ferry, l., Muther, N., Coulibaly, N., Martin, D., Mietton, M., Cissé Coulibaly, Y., Olivry, J.C., Paturel, J.E., Barry, M.A., Yéna, M., 2012. Le fleuve Niger de la forêt tropicale guinéenne au désert saharien - Les grands traits des régimes hydrologiques. IRD UNESCO.

Gardelle, J., Hiernaux, P., Kergoat, L., Grippa, M., 2010. Less rain, more water in ponds : a remote sensing study of the dynamics of surface waters from 1950 to present in pastoral Sahel. (Gourma region, Mali). Hydrol. Earth Syst. Sci. 14, 309-324.

Giorgi, F., Im, E.-S., Coppola, E., Diffenbaugh, N.S., Gao, X.J., Mariotti, L., Shi, Y., 2011. Higher hydroclimatic intensity with global warming. J. Clim. 24, 5309-5324. http://dx.doi.org/10.1175/2011JCLI3979.1.

Gosset, M., Viarre, J., Quantin, G., Alcoba, M., 2013. Evaluation of several rainfall products used for hydrological applications over West Africa using two high-resolution gauge networks. Q. J. R. Meteorol. Soc. 139, 923-940. http://dx.doi.org/10.1002/qj.2130.

Gray, D.M., 1972. Manuel des principes d'hydrologie. Comité national canadien de la decennia hydrologique internationnale, Ottawa, Canada (Chapitre VII).

Guilloteau, C., Gosset, M., Vignolles, C., Alcoba, M., Tourre, Y., Lacaux, J.P., 2014. Impacts of Satellite-Based Rainfall Products on Predicting Spatial Patterns of Rift Valley Fever Vectors. J. Hydrometeor 15, 1624-1635. http://dx.doi. org/10.1175/JHM-D-13-0134.1.

Habib, E., ElSaadani, M., Haile, A.T., 2012. Climatology-focused evaluation of CMORPH and TMPA satellite rainfall products over the Nile Basin. J. Appl. Meteorol. Climatol. 51, 2105-2121. http://dx.doi.org/10.1175/JAMC-D-110252.1 .

Herman, A., Kumar, V.B., Arkin, P.A., Kousky, J.V., 1997. Objectively determined 10-day African rainfall estimates created for famine early warning. Int. J. Remote Sens. 18, 2147-2159. http://dx.doi.org/10.1080/014311697217800.

Hermance, J.F., Sulieman, H.M., 2013. Comparing satellite RFE2 data with surface gauges for 2012 extreme storms in African East Sahel. Remote Sens. Lett. 4, 696-705. http://dx.doi.org/10.1080/2150704X.2013. 787498.

Hong, Y., Hsu, K., Moradkhani, H., Sorooshian, S., 2006. Uncertainty quantification of satellite precipitation estimation and Monte Carlo assessment of the error propagation into hydrologic response: error propagation from satellite rainfall. Water Resour. Res. 42, W08421. http://dx.doi.org/10. 1029/2005WR004398.

Hossain, F., Anagnostou, E.N., Dinku, T., Borga, M., 2004. Hydrological model sensitivity to parameter and radar rainfall estimation uncertainty. Hydrol. Process. 18, 3277-3291. http://dx.doi.org/10.1002/hyp.5659.

Hou, A.H., Kakar, R.K., Neeck, S., Azarbarzin, A.A., Kummerow, C.D., Kojima, M., Oki, R., Nakamura, K., Iguchi, T., 2013. The Global Precipitation Measurement (GPM) Mission. Bull. Am. Meteorol. Soc. http://dx.doi.org/10.1175/ BAMS-D-13-00164.1 (e-View)

Huffman, G.J., Bolvin, D.T., Nelkin, E.J., Wolff, D.B., Adler, R.F., Gu, G., Hong, Y., Bowman, K.P., Stocker, E.F., 2007. The TRMM Multisatellite Precipitation
Analysis (TMPA): quasi-global, multiyear, combined-sensor precipitation estimates at fine scales. J. Hydrometeorol. 8, 38-55. http://dx.doi.org/10. 1175/JHM560.1.

Hughes, D.A., 2006. Comparison of satellite rainfall data with observations from gauging station networks. J. Hydrol. 327, 399-410. http://dx.doi.org/10. 1016/j.jhydrol.2005.11.041.

Jobard, I., Chopin, F., Berges, J.C., Roca, R., 2011. An intercomparison of 10-day satellite precipitation products during West African monsoon. Int. J. Remote Sens. 32, 2353-2376. http://dx.doi.org/10.1080/01431161003698286.

Joyce, R.J., Janowiak, J.E., Arkin, P.A., Xie, P., 2004. CMORPH: a method that produces global precipitation estimates from passive microwave and infrared data at high spatial and temporal resolution. J. Hydrometeorol. 5, 487-503.

Krause, P., Boyle, D.P., Bäse, F., 2005. Comparison of different efficiency criteria for hydrological model assessment. Adv. Geosci. 5, 89-97.

Lebel, T., Parker, D.J., Flamant, C., Bourles, B., Marticorena, M., Mougin, E., Peugeot, C., Diedhiou, A., Haywood, J.M., Ngamini, J.B., Polcher, J., Redelsperger, J.L., Thorncroft, C.D., 2009. The AMMA field campaigns : multiscale and Multidisciplinary observations in the West Africab region. Q. J. R. Meteorol. Soc. 136 (S1), 8-33. http://dx.doi.org/10.1002/ qj.486.

Leblanc, M.J., Favreau, G., Massuel, S., Tweed, S.O., Loireau, M., Cappelaere, B. 2008. Land clearance and hydrological change in the Sahel: SW Niger. Glob. Planet. Chang. 61, 135-150. http://dx.doi.org/10.1016/j.gloplacha.2007.08. 011.

Mahé, G., Paturel, J.-E., 2009. 1896-2006 Sahelian annual rainfall variability and runoff increase of Sahelian Rivers. Compt. Rendus Geosci. 341, 538-546. http://dx.doi.org/10.1016/j.crte.2009.05.002

Mahé, G., Leduc, C., Amani, A., Paturel, J.E., Girard, S., Servat, E., Dezetter, A., 2003. Augmentation récente du ruissellement de surface en région soudano-sahélienne et impact sur les ressources en eau, in: hydrology of the Mediterranean and Semiarid Region, Montpellier. IAHS Publ. 278, 215-222.

Mahé, G., Paturel, J.-E., Servat, E., Conway, D., Dezetter, A., 2005. The impact of land use change on soil water holding capacity and river flow modelling in the Nakambe River, Burkina-Faso. J. Hydrol. 300, 33-43. http://dx.doi.org/ 10.1016/j.jhydrol.2004.04.028.

Mahé, G., Bamba, F., Soumaguel, A., Orange, D., Olivry, J.C., 2009. Water losses in the inner delta of the River Niger : water balance and flooded area. Hydrol. Process. 23, 3157-3160. http://dx.doi.org/10.1002/hyp.7389.

Maidment, D.R., 1992. Handbook of Hydrology. McGraw-Hill Company, Inc. (Chapter 10 Section 10.4.3)

Masson, V., Le Moigne, P., Martin, E., Faroux, S., Alias, A., Alkama, R., Belamari, S. Barbu, A., Boone, A., Bouyssel, F., Brousseau, P., Brun, E., Calvet, J.C., Carrer, D., Decharme, B., Delire, C., Donier, S., El Khatib, R., Essaouini, K., Gibelin, A.L., Giordani, H., Habets, F., Jidane, M., Kerdraon, G., Kourzeneva, E., Lafont, S., Lebeaupin, C., Lemonsu, A., Mahfouf, J.F., Marguinaud, P., Moktari, M., Morin, S., Pigeon, G., Salgado, R., Seity, Y., Taillefer, F., Tanguy, G., Tulet, P., Vincendon, B., Vionnet, V., Voldoire, V., 2013. The SURFEXv7.2 externalized platform for the simulation of Earth surface variables and fluxes. Geosci. Model Dev. 6, 929-960.

Moradkhani, H., Hsu, K., Hong, Y., Sorooshian, S., 2006. Investigating the impact of remotely sensed precipitation and hydrologic model uncertainties on the ensemble streamflow forecasting. Geophys. Res. Lett. 33, L12401.

Nash, Je, Sutcliffe, J.V., 1970. River flow forecasting through conceptual models part I - a discussion of principles. J. Hydrol. 10, 282-290.

Nikolopoulos, E.I., Anagnostou, E.N., Hossain, F., Gebremichael, M., Borga, M. 2010. Understanding the scale relationships of uncertainty propagation of satellite rainfall through a distributed hydrologic model. J. Hydrometeorol. 11, 520-532. http://dx.doi.org/10.1175/2009JHM1169.1.

Noilhan, J., Planton, S., 1989. A simple parametrization of land surface processes for meteorological models. Mon. Weather Rev. 117, 536-549.

Oki, T., Sud, Y.C., 1998. Design of Total Runoff Integrating Pathways (TRIP) - a global river channel network. Earth Interact. 2, 1-36.

Panthou, G., Vischel, T., Lebel, T., Blanchet, J., Quantin, G., Ali, A., 2012. Extreme rainfall in West Africa: a regional modeling. Water Resour. Res. 48, W08501. http://dx.doi.org/10.1029/2012WR012052.

Panthou, G., Vischel, T., Lebel, T., 2014. Recent Trend in the Regime of Extreme Rainfall in the Central Sahel.

Pearson, K., 1896. Mathematical contributions to the theory of evolution. III. Regression, heredity, and panmixia. Philosophical transactions of the royal society a: mathematical. Phys. Eng. Sci. 187, 253-318. http://dx.doi.org/10. 1098/rsta.1896.0007.

Pedinotti, V., Boone, A., Decharme, B., Crétaux, J.F., Mognard, N., Panthou, G., Papa, F., Tanimou, B.A., 2012. Evaluation of the ISBA-TRIP continental hydrologica system over the Niger basin using in situ and satellite derived datasets. Hydrol. Earth Syst. Sci. 16, 1745-1773. http://dx.doi.org/10.5194/ hess-16-1745-2012.

Peugeot, C., Esteve, M., Galle, S., Rajot, J.L., Vandervaere, J.P., 1997. Runoff generation processes: results and analysis of field data collected at the 
East Central Supersite of Hapex-Sahel experiment. J. Hydrol. 188-189, 179-202.

Pierre, C., Bergametti, G., Marticorena, B., Mougin, E., Lebel, T., Ali, A., 2011. Pluriannual comparisons of satellite-based rainfall products over the Sahelian belt for seasonal vegetation modeling. J. Geophys. Res. 116, D018201. http://dx.doi.org/10.1029/2011JD016115.

Roca, R., Chambon, P., Jobard, I., Kirstetter, P.-E., Gosset, M., Bergès, J.-C., 2010. Comparing satellite and surface rainfall products over West Africa at meteorologically relevant scales during the AMMA campaign using error estimates. J. Appl. Meteorol. Climatol. 49, 715-731. http://dx.doi.org/10. 1175/2009JAMC2318.1.

Sighomnou, D., 2012. Evènements de crues du mois d'Août 2012 sur le Niger. (Note Technique). Autorité du Bassin du Niger (ABN).

Sighomnou, D., Ilia, A., Tanimoum, B., 2010. Evènements de crue de juillet à septembre 2010 dans le niger moyen. (Note Technique). Autorité du Bassin du Niger (ABN).

Sighomnou, D., Descroix, L., Mahe, G., Moussa, I.B., Gautier, E., Mamadou, I., Vandervaere, J.-P., Bachir, T., Coulibaly, B., Rajot, J.-L., Issa, O.M., Dessay, N., Delaître, E., Maiga, O.F., Diedhiou, A., Panthou, G., Vischel, T., Yacouba, H., Karambiri, H., Paturel, J.E., Diello, P., Mougin, E., Kergoat, L., Hiernaux, P., 2013. La crue de 2012 à Niamey : un paroxysme du paradoxe du Sahel? Sécheresse 24, 3-13. http://dx.doi.org/10.1684/sec. 2013.0370.

Sorooshian, S., Hsu, K.L., Gao, X., Gupta, H.V., Iman, B., Braithwaite, D., 2000. Evaluation of PERSIANN system satellite-based estimates of tropical rainfall. Bull. Am. Meteorol. Soc. 81 (9), 2035-2046.
Spearman, C., 1904. The proof and measurement of association between two things. Am. J. Psychol. 15, 72. http://dx.doi.org/10.2307/1412159.

Stisen, S., Sandholt, I., 2010. Evaluation of remote-sensing-based rainfall products through predictive capability in hydrological runoff modelling. Hydrol. Process. 24, 879-891. http://dx.doi.org/10.1002/hyp.7529.

Thiemig, V., Rojas, R., Zambrano-Bigiarini, M. Levizzani, V., De Roo, A., 2012. Validation of satellite-based precipitation products over sparsely gauged African River Basins. J. Hydrometeorol. 13, 1760-1783. http://dx.doi.org/ 10.1175/JHM-D-12-032.1.

Thiemig, V., Rojas, R., Zambrano-Bigiarini, M., De Roo, A., 2013. Hydrological evaluation of satellite-based rainfall estimates over the Volta and BaroAkobo Basin. J. Hydrol. 499, 324-338. http://dx.doi.org/10.1016/j.jhydrol. 2013.07.012.

Vischel, T., Lebel, T., 2007. Assessing the water balance in the Sahel: impact of small scale rainfall variability on runoff. Part 2: idealized simulation of runoff sensitivity. J. Hydrol. 333, 340-355.

Weedon, G.P., Gomes, S., Viterbo, P., Shuttleworth, W.J., Blyth, E., Osterle, H., Adam, J.C., Belllouin, N., Boucher, O., Best, M., 2011. Creation of the WATCH Forcing data and its use to assess global and regional reference crop evaporation over land during the twentieth century. J. Hydrometeorol. 12, 823-848. http://dx.doi.org/10.1175/2011JHM1369.1.

Xie, P., Arkin, P.A., 1997. Global precipitation: a 17 -year monthly analysis based on gauge observations, satellite estimates, and numerical model outputs. Bull. Am. Meteorol. Soc. 78 (11), 2539-2558. 